\title{
LASHED TO THE MAST?: \\ THE POLITICS OF NOTIONAL DEFINED CONTRIBUTION PENSION REFORMS
}

\author{
Sarah Brooks and R. Kent Weaver* \\ CRR WP 2005-04 \\ Released: January 2005 \\ Draft Submitted: January 2005
}

\author{
Center for Retirement Research at Boston College \\ 550 Fulton Hall \\ 140 Commonwealth Ave. \\ Chestnut Hill, MA 02467 \\ Tel: 617-552-1762 Fax: 617-552-1750 \\ http://www.bc.edu/crr
}

* Sarah M. Brooks is an assistant professor of political science at Ohio State University. R. Kent Weaver is Professor of Public Policy and Government at Georgetown University and a Senior Fellow in Governance Studies at The Brookings Institution. The research reported herein was performed pursuant to a grant from the U.S. Social Security Administration (SSA) to the Center for Retirement Research at Boston College (CRR). The opinions and conclusions are solely those of the authors and should not be construed as representing the opinions or policy of SSA or any agency of the Federal Government, the CRR, the Luxembourg Income Study, or the Brookings Institution.

(C) 2004, by Sarah M. Brooks and R. Kent Weaver. All rights reserved. Short sections of text, not to exceed two paragraphs, may be quoted without explicit permission provided that full credit, including (C) notice, is given to the source. 


\section{About the Center for Retirement Research}

The Center for Retirement Research at Boston College, part of a consortium that includes a parallel centers at the University of Michigan and the National Bureau of Economic Research, was established in 1998 through a grant from the Social Security Administration. The goals of the Center are to promote research on retirement issues, to transmit new findings to the policy community and the public, to help train new scholars, and to broaden access to valuable data sources. Through these initiatives, the Center hopes to forge a strong link between the academic and policy communities around an issue of critical importance to the nation's future.

\section{Center for Retirement Research at Boston College \\ 550 Fulton Hall \\ 140 Commonwealth Ave. \\ Chestnut Hill, MA 02467 \\ phone: 617-552-1762 fax: 617-552-1750 \\ e-mail: crr@bc.edu \\ http://www.bc.edu/crr}

\section{Affiliated Institutions:}

American Enterprise Institute

The Brookings Institution

Center for Strategic and International Studies

Massachusetts Institute of Technology

Syracuse University

Urban Institute 


\begin{abstract}
:
Over the past decade, a number of countries have adopted a new form of pension system known as "notional defined contribution" (NDC) pensions. Like traditional defined benefit (DB) pensions, NDC pensions operate largely on a pay-as-you-go basis, but base benefits on total lifetime contributions rather than those in a specified number of peak earnings years. Payroll tax rates are (at least in theory) permanently fixed, while adjustments necessitated by demographic change and slow economic growth are automatically made on the benefit side. The authors argue that adoption of NDC-based reforms reflects political as well as policy considerations. The article analyzes a variety of conditions that have led some countries to adopt NDC-based reforms while such reforms have not even reached the agenda in others. The authors point out a number of problems that may arise during implementation of NDC-based reforms that undercut their potential benefits, and argue that erosion of NDC-based reforms is more likely than outright reversal.
\end{abstract}




\title{
LASHED TO THE MAST?: THE POLITICS OF NOTIONAL DEFINED CONTRIBUTION PENSION REFORMS
}

\author{
Sarah M. Brooks, Ohio State University \\ and \\ R. Kent Weaver, Georgetown University and The Brookings Institution ${ }^{1}$
}

In the final decades of the twentieth century, governments around the world began to dramatically change the form and function of old age pension systems. These reforms were generally motivated by a combination of population aging, slowing economic growth and tightening budget constraints, which led both to rising pension costs and declining resources with which governments could finance old age pension liabilities (See for example Pierson 1998, 2001).

Many governments responded to these pressures by revising the parameters of traditional defined benefit pay-as-you-go (PAYG) public pension systems through incremental changes to contribution or benefit rates, retirement age or indexation rules, in order to keep pension systems in line with changing economic and demographic trends and state fiscal capacity. Other governments, however, opted for more fundamental structural revisions of the design and objectives of old age pension systems through the creation of mandatory individual, fina ncial defined contribution (FDC) pension schemes, wherein pension benefits are based on individual contributions to a (typically) privatelymanaged pension fund, and the market return to capital on those funds. Throughout the 1990s, the ideas and technology behind funded pension schemes were disseminated broadly throughout the world. By the end of the decade, more than 20 countries from South Americ a to East Asia, Europe and the former Soviet Union had adopted funded, defined-contribution pension schemes either as the dominant 'pillar' in mandatory pension schemes, or as part of multi-pillar structural reforms (see for example Brooks, 2002; Madrid, 2003). 
By the middle of the 1990s, however, a new model of structural pension reform the non-financial (or notional) defined contribution (NDC) scheme - had also emerged. The NDC approach was the key feature of a national pension reform in Sweden that was adopted as framework legislation in 1994 and as final legislation in 1998. Latvia, Italy and Poland followed Sweden's lead.

Non-financial defined contribution pensions combine the pay-as-you-go financing that is characteristic of traditional defined benefit (DB) schemes with the defined contribution (DC) structure of individual accounts. NDC schemes tie benefits closely to individual contribution history over an entire working life, but credit those contributions with a notional interest rate tied to wage growth or overall economic growth rather than the return on specific financial assets. Notional accounts contain no real capital that can be claimed at retirement as a lump-sum or used to purchase an annuity in the private market. Instead, at the time of retirement, the government converts the notional account balance into an annuity on the basis of cohort life expectancy, and finances this benefit on a pay-as-you-go basis.

Although NDC pension schemes represent an important departure from both the incremental reforms of defined-benefit schemes and from individual account, pre-fundedDC models, many of the individual elements of the NDC scheme design that allow it to control costs are not new; they have been utilized on an ad hoc and often temporary basis in incremental reforms to pay-as-you-go DB pension schemes. The originality of NDC lies primarily in combining those elements into a coherent package with a clear policy objective, and imbuing that package with presumed perpetuity.

A number of "good policy" arguments have been advanced for adopting NDC measures. First, proponents cite the enhanced 'fairness' associated with the DC formula as compared to DB schemes that base retirement benefits on the last salary or last few 
years' wages, which tend to redistribute implicitly toward high-income workers with steeper earnings profiles. NDC schemes make any redistribution more explicit by removing it from the main NDC pillar of the pension scheme and creating a separate scheme with the objective of poverty reduction. Second, supporters of NDC-based reforms argue that the tighter link between contributions and benefits sends signals to workers that it is important to work longer to secure an adequate pension, thus enhancing system financing along with individual responsibility and work effort. Third, NDC-based reforms ensure a long-term balance between pension contributions and payouts. Fourth, NDC reforms do not expose individuals to short- and medium-term fluctuations in market returns and annuity prices that may arise in FDC individual accounts. Fifth—and of particular importance to government finance ministries-NDC pension reforms may provide a fiscally attractive alternative to funding the transition to funded DC because they do not require the government to finance benefits for a transitional generation as a country moves to a system of funded individual accounts.

A final potential advantage offered by NDC reform is the perception of permanency, and hence credibility, that it imparts to the social security system. By reducing the need for governments to intervene regularly to adjust pension system parameters, the 'political risk' of policy change in response to political pressures associated with public pension systems is significantly reduced. Indeed, the repeated tinkering with rules of DB systems in many countries has made those systems much less of a "defined benefit" in practice than in theory, especially for future retirees whose benefits are most likely to be affected. The sense of "ownership" felt by workers who receive regular statements tracking their rising notional account balances reinforces this sense of permanency of the NDC scheme. The resulting sense of property rights may 
create a 'lock-in' effect that deters politicians from intervening to arbitrarily reduce or confiscate the notional capital accumulated in the NDC accounts.

On the negative side, however, because NDC schemes accommodate increasing longevity completely through benefit reductions, stabilizing pension contribution rates will lead to gradual erosion of pension values as populations age if workers do not postpone their retirement.

This discussion of potential lockin and political risk suggests that political calculations as well as policy advantages and disadvantages may play a very important role in policymakers' calc ulations on NDC-based reforms. Indeed, the central working hypothesis in this paper is that NDC-based pension systems offer important political advantages to politicians in an era when credit-claiming opportunities in pension policy are few and blame-avoiding incentives are strong. In particular, it:

- Provides a "clean hands" mechanisms that lowers replacement rates as the system is phased in while allowing politicians to avoid blame;

- Obfuscates the degree of future retrenchment because it is not known in advance but rather depends on future economic and demographic developments and;

- Avoids having to repeatedly deal with pension retrenchment and refinancing in the future.

In short, the complexity and automaticity of the NDC scheme creates important opportunities to limit traceability and blame for benefit retrenchment: automatic adjustment mechanisms based on economic and demographic trends absolve politicians of responsibility for potential future benefit reductions. Like Ulysses in resisting the Sirens, governments may be able to "lash themselves to the mast" of a fixed contribution rate and automatic adjustment mechanisms, resisting temptations to pay unsustainable benefits to current and future retirees. 
The adoption of NDC schemes may also generate new political risks, however, because they accommodate increased liabilities (such as from unanticipated longevity gains) or revenue shortfalls (e.g., due to wage decline) by reducing benefits. To the extent that benefit values for younger birth cohorts fall short of public expectations regarding the absolute and relative value of pensions, politicians may confront a powerful political backlashas populations age. This may in turn lead to a "loosening of the lashes" on contribution rates and automatic adjustments, to contributions to the system from the general government budget, and/or to pressure for enhanced "social protection" pensions outside the NDC pillar.

The spread of Non-financial Defined Contribution-based pension reforms thus raises important questions both for social science theory and for pension policymaking. From the perspective of social science theory, NDC-based pension reforms represent an important example of what Jon Elster has called "pre-commitment" or "self-binding" efforts to limit fut ure options in a way that furthers their long-term interests. Indeed, Elster uses the Ulysses and the Sirens metaphor in much of his writing on precommitment (Elster 1979, 2000). NDC-based pension reforms can also be seen as a combination of several bla me-avoiding strategies that allows politicians to reconcile their policy and political objectives by making politically risky decisions through what Kent Weaver $(1986,1988)$ has called "automatic government" mechanisms rather than requiring politicians to make them openly. Thus NDC systems do not represent a departure from the common practice in PAYG-DB pension systems of making hard-todetect revisions, such as revisions to indexation rates, in order to achieve fiscal and policy goals.

Examining the adoption and implementation of NDC-based pension reforms provides an opportunity to examine how agenda-limiting pre-commitment mechanisms 
are adopted and how they operate in practice. Two questions are addressed in this study. First, are NDC-based reforms more likely to get on the agenda and win adoption in some countries rather than others? If so, is it characteristics of a country's current pension system, the political ideology of elites, or the characteristics of the political system—or some combination of these and other factors - that determines whether countries consider and adopt NDC-based reforms? Second, do NDC-based reforms actually succeed in depoliticizing painful and costly pension retrenchment decisions and limiting blame to incumbent politicians, or do they have a tendency to spark resistance that undercuts their intended effects?

In the first section of the paper we briefly outline the characteristics of Nonfinancial Defined Contribution pension systems, arguing that NDC pension schemes should be seen as a set of principles that may be more or less closely followed in practice. The second section develops a framework for analyzing why NDC pension systems have increasingly been on the agenda in recent years and discusses conditions that facilitate consideration and adoption of NDC-based reform, including the complex question of why there has been a stronger move toward adopting NDC in some countries and regions than others. The third section of the paper examines implementation challenges that may arise in NDC systems as they are adopted and mature, as well as their political sustainability. The final section of the paper assesses the prospects for a further spread of NDC pension systems. In short, the paper asks whether and under what conditions a doption of NDC pensions is likely to be an effective means of allowing politicians to "lash themselves to the mast" of a stabilized contribution rate and depoliticize the process of pension retrenchment. This, in turn, plays into the broader question of whether NDC-based reforms are likely to play a major role in addressing the immense aging issue facing both developed and developing societies in coming decades. 


\section{HOW NDC WORKS}

Although the NDC system represents a synthesis of the PAYG-DB and FDC systems, it differs from these in the way it apportions risk and reward, and in its likely political consequences. Although notional accounts share with FDC schemes a tight link between pension benefits and individual contributions, NDC systems are by design not advance-funded (Palmer, 2005 forthcoming). As noted above, NDC schemes also differ markedly from FDC systems in their treatment of capital market risks. NDC systems diminish individuals' exposure to fluctuations in market rates of return and annuity pices associated with privately-managed funded-DC schemes by using a notional interest rate. Workers in NDC schemes continue to be exposed to significant demographic risks, however, such as unanticipated gains in longevity during working life, and to sustained declines in fertility around the time of retirement. By shrinking the overall contribution base to the pension system, such trends would cause declines in pension benefits in order to maintain overall financial balance of the NDC system (Palmer and Góra, 2003). ${ }^{2}$ At the same time, the annual indexation of annuities to wage growth exposes retired workers to the risk of declines in benefits if wages and productivity fall.

NDC systems also differ from traditional DB schemes in important ways, as shown in the first and fourth columns of Table 1, which show different gradations of Non-financial Defined Benefit and Non-Financial Defined Contribution pension schemes. But as the second and third columns of the table show, a number of "middle positions" between DB and NDC pension schemes are possible on many of these key elements of pension system design. Some elements associated with NDC pension systems, such as life expectancy adjustments, have been enacted as ad hoc reforms of existing DB pension systems (column 2). And NDC-based systems sometimes take a "weak" or "partial" form, with one or more provisions that make them less than fully 
self-sustaining or inclusive (column 3). Table 1 divides these elements of pension system structure into four categories: structural features, coverage, time horizon, and exclusivity.

\section{Structural Features}

A wide range of variation is possible on multiple dimensions of the structural features of pension systems (Table 1). For example, while most non-financialDB pension schemes operate solely on a pay-as-you-go basis, the Swedish NDC scheme incorporates "buffer funds" that pre-fund some benefits and protect against small dips in contributions and demographic bulges in the population of retirees. ${ }^{3}$ Indeed, proponents of NDC argue that buffer funds should in principle be included in an NDC scheme (Palmer, 2005 forthcoming).

With respect to population aging — and in particular rising life expectancy at retirement-PAYG-DB schemes generally do not make provision for automatic adjustments to the changing demographic, social and economic context in which the system is embedded. Thus as populations age, they may require periodic government intervention to adjust benefit levels or retirement ages. NDC schemes automatically accommodate changes in life expectancy by calculating annuities on the basis of individual accumulations and life expectancy at the time of retirement. But such measures can also be included in DB schemes to partially or fully adjust for population aging, for example — in Germany—-the Kohl government's "demographic factor" enacted as part of a short-lived pension reform and the "sustainability factor" enacted by the current Schröder government (Börsch-Supan and Wilke, 2003). Similarly, public PAYG DB schemes generally include a fixed standard retirement age, usually with some sort of adjustment (which varies greatly across countries in its actuarial accuracy) for earlier or later retirement. A number of countries have raised the standard age in recent years in response to population aging. The Swedish NDC scheme, on the other hand, has replaced 
the standard retirement age with a flexible retirement age (pensions can be drawn no earlier than age 61), no upward age at which pension rights can be earned, and with the benefit based on the life expectancy of the retiree's birth cohort at the time of retirement. But NDC-like proposals have also been made for retirement age changes in public PAYG-DB, such as proposals in the United States that would raise the age for receipt of "full" Social Security entitlements as longevity increases.

Perhaps the most distinctive attribute of NDC pension systems is the fixing of a long-term contribution rate and the wage base, usually with the adjustment of account values for some index of wages. With this "lashing to the mast" of contribution rates, future adjustments to keep pension systems sound must in theory be made on the benefit side. For DB pensions operated on a PAYG basis, on the other hand, payroll tax contribution rates and wage bases are usually adjusted on an ad hoc basis as current funding needs change. A number of countries also use general revenues or some other form of revenue (e.g., the German eco-tax) to finance part of their PAYG DB pension system costs. Given increased longevity in most countries and flagging employment growth in a number of countries, there has been strong upward pressure on DB pension contribution rates over the past thirty years. ${ }^{4}$

In response to this trend, many countries have in recent years tried to stabilize contribution rates to their defined benefit pensions through a variety of mechanisms. In Canada, for example, the federal and provincial governments have pledged to keep payroll taxes under 10 percent in the long term; if benefit costs are projecte $\mathrm{d}$ to exceed that target within a specified projection period, a combination of benefit cuts and contribution rate increases is automatically triggered. ${ }^{5}$ Germany, where pension contribution rates grew to over 20 percent of earnings in recent years, has also acted to try to stabilize contribution rates at no more than 20 percent through the year 2020 and 22 
percent through 2030 (Gern: 2002, p. 457). In the United States, congressional Republicans made it very clear at the time of the 1983 Social Security rescue package that they would tolerate no further increases in contribution rates, and there have been none (Light, 1995). In short, even without the explicit "lashing to the mast" of contribution rates associated with NDC pension reforms, public non-financial DB systems can and have undertaken a number of actions to stabilize contribution rates.

Non-financial DB and NDC pension systems also differ significantly in their potential for intergenerational redistribution. DB pensions typically offer a much higher rate of return on contributions to the first generations in the program, when the ratio of contributors to beneficiaries is much higher than in later generations (especially as longevity increases). NDC pensions, on the other hand, are intended to restrict intergenerational redistribution. However, several PAYG-DB pension schemes, notably in Canada and the United States, have also moved to restrict intergenerational redistribution by making very long-term projections of contribution rates and benefit cos ts and developing contribution rates and benefit levels that are intended to be stable over that projection period with the support of reserve funds ${ }^{6}$

In principle, NDC schemes treat all contributions to the system the same in terms of accruing credits (with adjustments for wage or-as in Italy_GDP growth over time): only actual contributions accrue credits, and all credits result in equal payouts (actuarially adjusted for life expectancy at retirement). If credits are granted for other reasons, they must be accompanied by financing from general tax revenues, or the financial equilibrium of the system will be jeopardized. Even NDC systems may contain some elements of intra-generational redistribution in payout, however, notably in the use of gender neutral annuitization tables that do not reflect real gender differences in life expectancy. 
Many PAYG DB schemes include more complex patterns of intra-generational redistribution. Some countries, notably the United States, offer higher replacement rates for the first dollars of earnings, effectively offering a higher replacement rate for lowearners. Many PAYG DB schemes also base benefits on a contributor's highest or final number of earnings years (for example, the highest three, fifteen, or twenty years). To the extent that the benefit formula is based on final salary or only the latest years' earnings, it privileges workers with a steeper career earnings profile. Such workers are typically the most affluent and better-educated in society. In recent years, public PAYG DB pension systems in many countries have been altered to limit redistribution within generations in some ways, for example by lengthening the number of contribution years used in calculating pension entitlements or flattening replacement rate differentials across earnings levels. But there has also been a widespread expansion in non-contributory credits given for care-giving in a number of countries.

The use by NDC schemes of a benefit formula based on contributions over the entire career both diminishes the degree of regressive redistribution caused by final salary benefit formulae and at the same time eliminates the possibility for progressive redistribution of pension benefits. The overall progressivity of an NDC-based retirement income system thus depends critically on the existence of mechanisms within or outside the NDC component to progressively reapportion risk and benefits to the least well-off. This can be done in either of two ways. First, contributions can be made for individuals that increase their benefit entitlement: in Sweden, for example, contributions are made into the system for periods spent in child care-giving, military service, unemployment, sickness and disability covered by public social insurance, and for compensated parental leave and higher education. The money to finance these credits is transferred from the general budget to the NDC reserve fund on a yearly basis. Partial NDC reforms have 
imputed credits without financing them immediately, but these elements require a future tax-based transfer burden to make the system sustainable. Second, changes may be made in other tiers of the retirement income system that add or "reinvent" existing redistributive elements, such as by topping-up benefits to a minimally-guaranteed level. To date, all countries introducing NDC have constructed a minimum benefit guarantee financed from general revenues. Indeed, without an adjustment of other pension tiers to ease the transition to NDC, the distributional change resulting from a change to NDC is likely to impose such heavy costs on some groups that its chances of winning adoption and being sustained are substantially reduced.

\section{Time Horizon}

Pension reforms can also be distinguished by their phase -in periods. The U.S. increase of retir ement age from 65 to 67 , for example, is being phased in over almost 40 years from when it was enacted to when it will be fully in effect. To date, countries implementing NDC reforms also show great differences in the time horizon over which they phase in their reforms. NDC reforms can be applied to rights acquired under the previous system, if adequate contribution records exist. ${ }^{7}$ In the Swedish reformlegislated between 1994 and 1998, for example, all workers born after 1953 are entirely in the new system; earlier cohorts born between 1937 and 1953 are partially in the new system. In Italy, on the other hand, only new entrants to the labor market will have their benefits fully calculated under the new NDC rules. A longer phase-in period is likely to weaken opposition from the most attentive publics — the elderly and near-elderly — but it also lessens near-term budgetary savings from reform. 


\section{Coverage}

Countries can also differ in the degree to which the NDC system will apply to all members of the workforce when it is fully phased in. Excluding key sectors (e.g., the military, or as in Poland, farmers) from a shift to NDC may help governments manage the politics of reform, although doing so clearly raises questions of equitable treatment. It will also mean that career changes into a sector covered by NDC can entail losing benefit privileges in the sector that workers migrate from.

\section{Exclusivity}

Most countries have multi-pillar pension systems. Thus even when an NDC system is fully phased in, it may not be the sole, or even the largest, source of public pension income. The 1994 pension reform in Sweden, for example, created a multipillared pension scheme in which the average wage worker could expect to receive a retirement pension from an NDC account and a mandatory individual financial DC account. There is also a garantipension financed from general revenues for low-wage workers and workers with interrupted earnings histories, which tops up their accumulated pension accounts to a socially-acceptable minimum. The NDC tier is dominant however financed by a $16 \%$ payroll contribution, compared to a contribution of $2.5 \%$ of covered wages into financial (i.e., funded) individual accounts. The Polish government similarly adopted a mixed, NDC and funded-DC scheme, wherein 15 percent of covered wages are credited to the first (NDC) pillar and indexed with a notional interest rate equal to growth in the covered wage bill. Nine percent of covered wages are transferred to the funded scheme in Poland, and invested according to market principles (Góra and Rutkowski, 2000). The Latvian pension reform also combines an NDC pillar with a financial DC scheme. The NDC pillar was financed with contributions of $20 \%$ of covered wages from the outset, indexed to the growth in the wage bill (average wages plus labor market 
growth). The individual financial account scheme, which came into force in 2001, initially received $2 \%$ of covered wages, while contributions to the NDC component decreased to 18 percent. Following a transition schedule specified in the law, the split will be 10 percent and 10 percent by 2010 (Fox and Palmer, 1999 and Holzman and Palmer, 2005 forthcoming).

Overall, the preceding discussion suggests that a political analysis of Nonfinancial Defined Contribution pension systems must recognize that the boundaries between NDC and non-financial DB pensions are fuzzy rather than sharp. Not only have certain elements of NDC, such as life expectancy adjustments, been used since the mid1990s on an ad hoc basis in incremental DB reforms, but also countries like Italy have adopted partial NDC reforms in ways that may be unstable in the mediums or long-term. In the case of I taly, for example, the government imputes contributions to notional accounts for some groups higher than those that are actually made. At the same time, the Italian system does not have automatic stabilizers, nor does it automatically take into account pre- or post-retirement increases in longevity. Finally, Italy has established an inflexible rate of return on acc umulated contributions, raising questions as to the medium to long-term stability of the system(Franco and Sartor, 2005 forthcoming). If incomplete adoption of NDC is possible, so too, presumably, is an incomplete dismantling: thus an analysis of NDC politics must also include an assessment of the risks of an ad hoc unraveling of NDC reforms.

Despite the tighter link between contributions and benefits, moreover, NDC schemes may nonetheless bear the heavy imprint of political values, objectives, and concessions to powerful domestic political groups. Governments may intervene in the accumulation phase of the NDC system, for instance, to credit socially-valued activities 
that are not rewarded by markets, such as the provision of credits for child rearing, education and military service. At the same time, powerful groups such as the military or specific industrial sectors may claim privileges within the NDC framework to the extent that governments credit notional accounts for workers in these sectors to finance special benefits such as early retirement. ${ }^{8}$ The use of unisex mortality tables likewise represents a political decision to redistribute from men to women. The redistribution of credits accumulated by wor kers who die before retirement also represents a political judgment in which the claim of survivors within the family is weighed against those of workers within the cohort, to whom such credits are otherwise apportioned (as in Sweden and other countries adopting NDC to date).

\section{THE POLITICS OF NDC INNO VATION, DIFFUSION AND ADOPTION}

The discussion above suggests some important general propositions about the politics of adopting NDC-focused pension reforms. First, it suggests that while NDCbased reforms have some features that may be politically attractive for re-election oriented politicians_-in particular the capacity for politicians to distance themselves from long-term benefit and eligibility cuts — they are not without political drawbacks as well.

Second, it suggests that the attitudes of important actors in pension reform politics—notably Finance Ministries, trade unions and groups representing retirees —are likely to be heavily influenced by what else is in the pension reform package, notably what protections are afforded to the aged through the provis ion of income-tested pensions or supplemental DC pensions to compensate for any losses, and who is expected to pay for the costs for those parts of the reform package.

Third, this analysis suggests that proponents of an NDC-based reform may be able to affect the political prospects for reform through specific design features in the 
reform. In particular, the pace of transition strongly influences the degree and visibility of the material and distributive effects of NDC reforms, and thus the political via bility of these measures. If a reform is phased in quickly, the terms of the new scheme are not only more costly and transparent, but are also at greater risk of political backlash. Other features of NDC program design that are likely to affect a proposal's political prospects include provisions of other pension tiers and how they compensate any losers from the shift to NDC (e.g., the creation of new income-tested pensions), as well as which groups (e.g., civil servants or the military), if any, are excluded from a shift to NDC. There may also be significant battles over whether and how much to provide credits for non-wage related benefits within an NDC pension scheme, as well as over the question of who should pay for those credits.

Finally, the politics of NDC adoption and rejection is likely to be a moving target. How politicians perceive and react to NDC proposals is likely to evolve over time as the concept is diffused more broadly among technocratic elites and experience with implementation of NDC-based pension regimes grows.

This very general overview of the calculus of key actors does not take us very far, however, toward understanding why NDC pension reforms are likely to get on a government's agenda and win adoption in some countries and not in others, let alone whether an NDC-based reform will be sustained once it has been adopted. In order to understand these cross-national variations and how they are likely to evolve over time, it is important first to introduce contextual factors that vary across countries, notably the severity of the challenges that extant pension systems face, the weight of various social actors, and the barriers that a political system imposes to instituting major reforms. Second, it is important to take a process-oriented a pproach, distinguishing between the forces that are critical at different stages of NDC politics: (1) initial development of the 
NDC idea and its first application; (2) diffusion of the concept to the agendas of other countries;(3) adoption or rejection of the NDC idea once it is on a government's agenda in a specific country; and (4) sustaining an NDC reform once it is in place. Third, it is important to examine whether NDC is adopted fully or partially — that is, the structural features, coverage, time horizon and exclusivity of NDC-based schemes in particular countries. Thus we can imagine a continuum of outcomes ranging from early "full" adoption of NDC-based reform to partial and/or later adoption, to consideration and rejection of NDC-based reforms to the issue never making it onto the agenda, as shown in Table 3. (Of course, countries may shift over time between categories). Since the NDC "innovation" is now well-developed, we will first examine the diffusion of NDC-based reforms and their full or partia 1 adoption or rejec tion. ${ }^{9}$ Sustaining implementation of NDC-based reforms will be considered in the next section of the paper.

\section{Agenda Setting and Adoption}

A critical component of any institutional reform process is the task of formulating the policy problem and placing the issue on the political agenda. To Kingdon (1995), policy proposals are likely to reach and remain on a government's agenda only if they appear to be broadly congruent with the values of policymakers and the public, as well as politically feasible, affordable, and likely to make some improvement in a perceived policy problem. Of course, successful coupling of these dimensions is typically the work of a skilled policy entrepreneur. To Orenstein (2000), such "proposal actors" are critical in establishing the "intellectual agenda" of a reform. In addition to putting reform on the political agenda, proposal actors introduce new policy innovations and delimit the feasible range of policy outcomes for the country (2000, p. 12-13). Examining structural pension reforms in Eastern Europe and Central Asia, Orenstein found that where there are fewer, and more like-minded proposal actors, the possibility for adopting an ambitious structural reform were greatly 
enhanced. Importantly, however, while the incorporation of a broader range of interests in the early stages of reform (such as where disparate interest groups and government ministries advance reform proposals) tends to diminish the magnitude and pace of reform, to the extent that broad agreement (or "buy-in") is achieved during the agenda-setting phase, both the implementation and the longer-term prospects for sustainability are enhanced (Orenstein, 2000). Accordingly, we examine in the next sections the key factors shaping whether and to what extent countries move toward NDC pension reform. These include 1) whether the problem or challenge of structural pension reform is brought onto the national agenda and how the problem is defined by key actors; 2) whether the specific policy alternative of NDC pension reform is one of the options considered by policymakers; and 3) how policy feedbacks from existing pension regimes as well as 4) the structure of political institutions shape both alternatives considered and the prospects for NDC adoption.

In the first dimension, we examine the extent to which governments are pressed to reform state pension schemes by varying degrees of demographic change, budgetary constraints and macroeconomic pressures. Second, we discuss how exposure to, and hence adoption of, NDC ideas are influenced by the strength of various domestic ideological groupings as well as countries' interaction with supra-national institutions such as the European Union and the World Bank. In the third dimension, we examine how feedbacks from prior policy choices may make consideration and adoption of NDC-based reforms more or less likely, such as by shaping how the problem and its feasible solutions are perceived, and by influencing the political coalitions that have developed around current policies. Lastly, we examine how the structure of political institutions and political competition affect both the political advantages and costs associated with NDC systems, and hence the likely barriers to policy change. ${ }^{10}$ 
Table 3 outlines hypothesized relationships between specific variables and several possible outcomes (e.g., first innovation with NDC, early adoption, partial adoption, consideration and rejection of NDC, NDC never reaching agenda), while Table 4 develops an informal "scorecard" of the relationship between causes and outcomes. Specifically, the table highlights the hypothesized relationship between our key variables and the outcomes achieved by several countries with respect to NDC reform (e.g., with Sweden as innovator, Italy as a partial adopter of NDC, Uruguay as a country that rejected NDC in favor of a mix of DB and DC, and the United States as a country where NDC has not yet reached the agenda).

\section{Economic-Demographic Pressures for System Change}

The wave of structural pension reforms that began in the 1980s and swelled in the 1990s has been widely attributed to significant demographic and economic changes, which raised the specter (and reality) of wide deficits in social security budgets, and tighter pressures on overall government spending. These developments have clearly had a major impact on pension reform agendas.

Aging populations are a critical source of pressure for change in pension schemes. Most countries operate their pension systems on a pay-as-you-go (PAYG) basis, even where there is a dedicated payroll tax for pensions. Falling birthrates and life expectancy increases mean that there are fewer workers to support each retiree - a trend that is only expected to increase in future years. Demographic challenges vary significantly across nations, however (Kinsella and Velkoff, 2001; European Union, Economic Policy Committee, 2001). In general, we would expect that countries that have had a high percentage of their populations over age 65 for an extended period would be most likely to have exhausted incremental retrenchment and contribution reforms and be more likely to consider NDC and other sorts of fundamental pension restructuring initiatives. 
Consistent with this hypothesis, many of the early adopters of NDC (notably Sweden and Italy) are among the world's oldest societies.

Fiscal concerns also increased pressure for austerity in public pension systems. Rising government deficits and debt/GDP ratios are clearly likely to raise pressures for pension reform. But the effects of such a fiscal crunch are complex. Indeed, a quantitative study of 57 developed and developing countries has shown that countries with a high public debt to GDP ratio are less likely to privatize their pension programs (at least when pension liabilities are low or moderate), because they cannot afford the transitional costs associated with moving from a public PAYG to fully-funded individual accounts (Brooks, 2002: 513-515). For example, Pinheiro (2004: pp. 112,134) argues that Brazil's rejection of privatization in the late 1990s stemmed in large part from the high transition costs implied by such a measure. A plausible hypothesis is that a shift to NDC is probably most likely to at least get on a government's agenda where (1) a government faces severe fiscal pressure, and (2) a high debt/GDP ratio and/or current fiscal pressures inhibit a move to funded DC.

Strong concerns about economic competitiveness sparked in particular by high payroll tax rates may also increase interest in NDC-based reforms. Higher capital tax rates are also severely constrained as a revenue source (Swank and Steinmo, 2002; Swank, 1998; Garrett, 1998). NDC-based reforms offer the opportunity to "lash policy to the mast" of a permanently fixed pension payroll tax, while the exact implications of that change for individual beneficiaries are made contingent on future economic and demographic developments. In general, we would expect countries that already have very high payroll tax rates along with the prospect of rapidly aging populations to be most likely to consider NDC. Countries without a pre-existing payroll tax structure, like New Zealand, would likely find the transition to NDC politically and administratively very 
difficult. The data in Table 4 suggest that consideration of NDC-based reforms is associated with countries with high or very high overall payroll tax rates.

Overall, there does appear to be an association between strong demographic, fiscal and payroll tax rate pressures and the likelihood that an NDC-based reform reaches a country's policy agenda. Nevertheless, it is probably most accurate to infer from existing evidence that economic and demographic pressures are helpful in explaining when pension reform generally achieves agenda status, and when the alternative of a radical shift toward privatized individual accounts is less plausible. Thus, while demographic and economic pressures may have some impact on which policy responses are considered, they are insufficient to explain when NDC-based reforms in particular, rather than some other type of restructuring measure, are seriously considered or adopted.

\section{Ideational and International Forces}

In order to understand how and when the particular policy innovation of NDC pension reform is likely to be adopted in a given country, we must examine the ideational and international forces shaping the "policy stream," or range of options that are included in and excluded from serious policy debate (Kingdon, 1995). At least three types of forces are important to the flow of pension reform ideas.

First, the "intellectual agenda" is likely to be influenced in a given country by the strength of the domestic political base for conservative ideological critics of public PayAs-You-Go pensions. Specifically, we expect that proposals for pension privatization are likely to dominate debates over pension restructuring in countries where (1) the overall ideological climate; and (2) the ideology of the governing political elites is suspicious of governmental action and has strong faith in market solutions to policy problems. NDC solutions, by contrast, are more likely to be on the agenda where pressures for pension restructuring are strong, but the national (and governing political party/coalition) 
ideological climate is more favorable to government and less favorable to privatization and individual accounts. Intermediate outcomes (e.g., greater or lesser roles for NDC and FDC in a multi-pillar system) may occur when forces are more evenly balanced in a political system. Such prolonged haggling can in fact be observed in negotiations between the Social Democrats and non-socialist parties over the relative sizes of the NDC and "premium pension" (FDC individual account) tiers within the new Swedish pension system (Anderson and Weaver, forthcoming; Lundberg, 2003).

In addition to domestic sources of pension reform ideas, the policy models that gain agenda status may be "cued" from a second source: archetypal policy models or practices to which policymakers are exposed through informal regional networks of specialized policy elites (Bennett, 1991; Haas, 1992; Most and Starr, 1980). Beyond the cognitive ease of looking to relevant examples, rather than "reinventing the wheel," competitive and status concerns have entered prominently in the adoption of structural pension reforms in the past decade. ${ }^{11}$ In particular, government technocrats draw information about the viability of a policy model from the experiences of relevant, or "peer" nations. Such countries may be those that share similar structural conditions and policy regimes, or those with common demographic, economic or political structures. At the same time, peer nations may be those with which policy elites interact on a regular basis through regional organizations like the European Union and OECD, which actively promote policy diffusion—and harmonization—across member nations (Hering, 2004).

All of these factors suggest that at least initially, the dissemination of policy models is likely to be heavily regionalized — and available evidence confirms this hypothesis (Brooks, forthcoming; Madrid, 2003). Just as the Latin American nations looked more to the Chilean model than pension reformers in other regions, early adoption of the NDC system has been concentrated in Europe, with Italy, Poland, and Latvia 
among the early adopters, while recent German reforms contain elements of NDC, and NDC-inspired reforms are being considered in Norway, and the Czech Republic. The effect of such regional networks may weaken as diffusion mechanisms over time, however, as NDC ideas become broadly disseminated through professional networks of pension experts.

A third source of ideas and pressures for specific courses of pension reform transcends regional networks: "supra-national" institutions such as the European Union (for member countries) as well as international financial institutions such as the World Bank and International Monetary Fund. Scholars have long attributed a central role to international organizations in shaping domestic policy processes around the world through the diffusion of norms and ideas (Keohane and Nye, 1974; Finnemore, 1993; Krasner, 1992; see also Nelson, 2004; Weyland, 2004). We expect that some form of structural pension reform is more likely to get on the agenda when (1) a supra-national institution sets deficit and debt reduction targets for participation in its programs, as in the case of the European Union, (2) that NDC in particular is more likely to get on a government's agenda when a government participates in institution-sponsored networks where NDC ideas are active; and (3) that governments are more likely to adopt an NDCbased reform when they anticipate that a shift to NDC will aid them in obtaining loan approval or another desired outcome from the institution.

Supra-national institutions may influence a country's pension policy choice in several distinct ways, such as through loan conditionality (granting a loan is made contingent upon adoption of a specified policy), or by encouraging "anticipated reaction" (a country may adopt reforms that it thinks will win favorable action from the supra-national institution. Alternatively, national policy elites may use perceived or alleged threats of negative actions by the supra-national institution to win support for a policy change from reluctant domestic 
actors -in effect, making the international institution a "strategic scapegoat" in the reform process (Vreeland, 1999). Supra-national institutions also may act simply as agents of knowledge transfer for "best practices" from other countries. And lastly, such institutions may serve as a means of harmonization, encouraging member countries to develop common practices to lower regulatory barriers to labor and capital mobility.

Several of these channels can be seen in the pension austerity measures taken in European Union member countries. Perhaps most important, in countries such as Italy pension retrenchment was seen as necessary to meet the three percent of GDP target set for government deficits as a condition for entry into the European Monetary Union (Schludi, 2002). However, these actions by national policymakers largely took the form of "anticipated reactions" and strategic choices designed to win the acquiescence of domestic opponents of painful pension reforms (Franco and Sartor, 2005 forthcoming).The EU has also set other requirements (e.g., requiring gender neutrality in retirement ages) that have an impact on austerity policy choices and have led indirectly to modest policy harmonization.

Moreover, the EU has not even attempted to harmonize most aspects of the disparate pension systems of its member countries, and where it has tried to harmonize policies directly, notably in the area of supplemental pensions, it has had little success. While some analysts have argued that NDC-based reforms could serve as a vehicle for pension harmonization in the European Union (Holzmann, 2003), the European Commission itself has not endorsed such an approach. The absence of harmonization pressure within the EU helps to explain the absence of overall policy convergence on NDC or any other single model for pension restructuring in Western Europe.

Despite the importance of the EU among advanced industrial nations, few institutions have rivaled the global influence of the World Bank in the dissemination of 
the ideas and technology of multi-pillared pension reform. The World Bank's 1994 report Averting the Old Age Crisis brought unprecedented international attention to the issue of old age pension reform, fundamentally transforming the way that policymakers conceptualized the issues and solutions to the challenges of old age income reform. More concretely, the World Bank provided a knowledge base, resources to build institutional and technological capacity, financial support, and in some cases political cover (acting as "bad cop" to domestic politicians" "good cop") for governments to adopt some form of privately-managed funded pension schemes. ${ }^{12}$ Indeed, there is little doubt that the World Bank played a powerful role in promoting the adoption of structural DC pension reforms by disseminating policy ideas and technology to government technocrats. Moreover, by associating the shift from DB to DC (both financial and notional) structures with an array of micro and macroeconomic benefits, World Bank actors generated strong attraction to DC pension reforms among Finance Ministry and Central Bank policy makers in disparate corners of the world. ${ }^{13}$

While the International Labor Organization (ILO) and International Social Security Association (ISSA) disseminated competing ideas to those of the World Bank, the latter enjoyed important resource advantages over the ILO and ISSA, dedicating vastly greater human and financial resources to the research and dissemination of ideas and policy models based on the DC mechanisms (Brooks, forthcoming; Orenstein, 2003). Indeed, following the publication of its 1994 report, the World Bank social protection group launched a multi-year dissemination project, holding workshops and training seminars around the world. It likewise fostered cross-national policy sharing through a series of annual summer workshops that became a clearinghouse for pension reform ideas, bringing together academics, social security experts and policymakers from around the world to build connections and share ideas about pension reform. 
The World Bank has in recent years shown a growing awareness of the shortcomings of FDC pensions in Latin America and elsewhere (see in particular Gill et al, 2004), and has promoted the discussion of a wide range of pension reform modelsand in particular NDC-based reforms? rather than a single focus on FDC schemes. Indeed, the participation of socia 1 security experts from Sweden in these summer workshops opened up the NDC reform ideas to policymakers from far outside the original networks through which these ideas were carried in Europe. More generally, existing research provides little evidence to suggest that the loan conditionality has been the primary means through which international financial institutions have promoted social policy changes, including pension privatization or NDC-based reforms (Brooks,

2004a; Hunter and Brown, 2000). ${ }^{14}$ The predominant role of international financial institutions in influencing NDC and other pension reforms is in the agenda-setting process, by transmitting policy ideas and reform models through technocratic networks, rather than by coercing client governments to adopt specific reforms.

\section{Policy Feedbacks}

Once in place, public pension systems have a profound effect on subsequent battles over pension reform. The existing pension system defines not only the winners and losers of structural reform initiatives, it also delimits the range and intensity of issues over which beneficiaries of the status quo will fight. The structure and performance of the old pension system affects several important aspects of policy choice, including public expectations as to the 'proper' role of the government and the 'fair' level of redistribution in social security; the magnitude of vested interests in the status quo - who stands to gain and lose and how much; and the cost structure and implicit pension debt associated with the current policy as well as the transitional cost of moving from an 
unfunded to a funded system. In short, policy feedbacks powerfully shape the agendasetting process, making pension regime change heavily "path dependent" (Pierson, 1994, 2000). Three policy parameters that are prima facie likely to be conducive to both consideration and adoption of an NDC-based pension reform are: (1) a strong earningsrelated component to the pension system; (2) high implicit pension debt associated with generous replacement rates in a DB scheme, and (3) the existence of complete payroll tax records that allow compilation of lifetime earnings records for calculating benefits under an NDC scheme. ${ }^{15}$

First, NDC reforms are more likely where the existing system employs an earnings-related benefit structure (as in a Bismarckian social insurance model), because such a regime encourages public perceptions that a 'fair' pension scheme should allow benefits to bear some relation to contributions. If the contribution-benefit linkage is widely perceived to work poorly (e.g., by delivering benefits in a distorted or unfair fashion), however, or public confidence in the capacity of the public PAYG defined benefit system to pay benefits in the near- and medium-term has been very badly shaken, public support for tightening the link between benefits and contributions may be more easily cultivated.

The structure of the old pension system also creates important financial constraints on reform options. As noted above, if payroll taxes are already high to finance a public DB scheme, market pressures to increase flexibility and lower non-wage costs leave little room to increase contributions to social security. Adding to the constraints of high payroll taxes and well-organized constituents is the heavy implicit pension debt associated with high replacement rates in most traditional DB pension schemes (James, 1998). A large implicit pension debt makes the transition cost of a shift toward prefunding (for example, by diverting payroll contributions to individual accounts) very 
high. This transitional cost can in theory be financed through increased taxes, spending cuts, or by issuing new debt, but political and financial constraints may place these options out of reach for many governments.

In "Bismarckian" countries with a very large public earnings -related pension tier, pressures to reduce pension costs and reduce rathe $r$ than just stabilize pension contribution rates have been especially severe. Bismarckian countries are likely to begin with incremental retrenchment and refinancing measures, but as these have been exhausted, several have turned toward more fundamental restructuring reforms to reduce current and future costs. Because the public Pay-As-You-Go tier was already so large, however, proposals for a mandatory occupational or personal pension individual account tier had to adapt or be "crowded out" by the double payment problem. When expanded mandatory or quasi-mandatory individual account tiers have been adopted in these countries, notably in Sweden and Germany, it has been as a relatively small supplement to a still very large public pension tier that faced severe affordability problems. As Table 4 suggests, NDC-focused pension reforms initially emerged in countries like Sweden and Italy that offered generous "Bismarckian" pensions, for it is in these countries that current and future pension funding problems were most severe, and where the double payment problem made a DC-based alternative less feasible. In what can be called "Bismarckian Lite" countries, Canada and the United States, pension replacement rates and financing burdens are relatively modest. These countries are likely to be able to maintain their curre nt pension structures with incremental measures for some years into the future, and NDC-based reforms have not reached the agenda.

A third policy feedback that might be expected to make consideration and adoption of NDC-based reforms more likely is the existence of complete payroll records that allow retrospective calculation of lifetime earnings to establish NDC "account 
balances." In practice, however, this does not appear to be the case. Countries in Eas tern and Central Europe that do not have adequate retrospective wage records have developed alternative mechanisms to credit initial capital in NDC accounts (Palmer, ChlonDominczak and Góra, 2005 forthcoming).

\section{Political System Characteristics}

Specific characteristics of national political environments may also affect both the agenda-setting process - that is, whether a particular reform idea develops an institutional carrier that perceives political and policy advantages to a specific pension reform proposal? and the prospects for adoption once that proposal is on the agenda.

Understanding the development and diffusion of NDC-based pension reforms must begin with a recognition of the opportunities and costs that they impose for key actors in society. Within government, both elected politicians and Finance Ministries (or their equivalent ministries charged with budgetary and overall economic management) are likely to be involved in pension reform initiatives in most countries-frequently supplanting the social or labor ministries with direct responsibility for running pension programs (Orenstein, 2000).

Elected politicians are driven powerfully by the desire to avoid blame for costly policy adjustments (Pierson and Weaver, 1993). Altering public pension systems is especially risky, because even small but well-publicized losses among retirees or those retiring in the near future are especially likely to provoke opposition from the affected group. Moreover, in many countries, the elderly are disproportionately likely to vote. For state leaders pressed by demographic and economic change to diminish long-term state pension liabilities, NDC reforms represent a possible means to reduce pension expenditures and commitments while avoiding blame for doing so. ${ }^{16}$ In the short term, 
citizens (and politicians) who are unfamiliar with actuarial principles may be confounded by the NDC scheme. The contingency of future pension benefits on demographic and economic trends also makes it difficult for citizens to predict ex ante the precise material implication of NDC shifts. While this uncertainty could limit initial opposition to NDC, it might also foster exaggerated fears that increase opposition to a shift to NDC. Of course, voters might prefer the type of uncertainty associated with adopting NDC—cuts in benefits are likely to occur in the future, but they will be rule-based and likely to avoid complete system collapse? to the even greater uncertainty associated with future ad hoc cuts in current pension schemes that are highly likely to occur but uncertain in their timing, magnitude and targeting. But voters are likely to underestimate the certainty of ad hoc cuts and may exaggerate the magnitude of cutbacks that are known to be automatic but unknown in magnitude.

In the longer term, NDC schemes release politicians from responsibility for benefit reductions as demographic and economic profiles change. By adjusting benefits automatically to life expectancy, not only do governments avoid the need to make such changes, but they can escape responsibility for the benefit reductions triggered by the demographic and economic trends, since these lay beyond the immediate command of government. NDC reform thus offers the appeal as a meaningful structural reform from which politicians can walk away with "clean hands." 17

Finance ministry officials have likewise played an important role in the adoption of structural pension reforms. Their attitude toward, and activism in promoting, NDCbased pension reforms is likely to be conditioned by several factors. First, the importance of Finance Ministries is enhanced where fiscal pressures have been a primary motivator for pension reforms, and in countries facing strong international financial constraints, either from foreign investors, international financial institutions, or supra-national 
organizations such as the European Union. In Poland, for example, Góra and Rutkowski (2000) argue that Finance ministry officials' demands for macroeconomic discipline in 1991 became an important force moving the country toward structural pension reform. NDC reforms thus become attractive to Finance Ministry officials to the extent that budgetary pressures from unfunded DB schemes collide with medium-term constraints on government's ability to finance a private funded-DC reform. In Brazil, for example, although Finance Ministry officials favored a structural pension reform in early 1999, Central Bank official strongly resisteda mixed DB and funded-DC pension reform on account of the effect of such a reform's transition cost on short-term macroeconomic performance, which had come under intense international pressure following a currency crisis (Brooks, 2004a: 75).

However, the attitude of Finance Ministry officials toward NDC pension reform may also be heavily influenced by the overall design of the pension reform package: if, for example, the tighter linkage between contributions and benefits is accompanied by a requirement that greatly increased general government revenues be used for nonemployment credits (e.g., for care of young children) and for expanded non-contributory pensions for low-earners, then such officials are likely to balk.

Political institutions may also affect the prospects for adoption of NDC proposals once they are on the agenda. First, a substantial literature suggests that multiple veto points in the policy adoption process can lower both the probability of any change from the policy status quo (see Immergut, 1992; Tsebelis, 1999) and the scope of any change that is adopted. ${ }^{18}$ The passage of significant pension reforms should be particularly difficult in countries with large, multi-party governments where government leaders need to build majorities across parties occupying a broad range of ideological positions. ${ }^{19}$ Indeed, Sweden, Latvia, Poland, and Italy are all proportional representation systems in 
which a large number of parties held seats in the legislature at the time that an NDC or NDC-oriented reform was passed. ${ }^{20}$ In each of these countries, such reforms were adopted following intense negotiations across a diverse set of parties.

Beyond the compromises embodied within the structure of the NDC scheme, each country also combined distinct pillars of the social security system in such a way that satisfied demands of diverse coalition partners and organized interests, while working within the financial and political constraints of the old pension system. Importantly, while such broad negotiations may diminish the magnitude and pace of reform, they may have a positive, longer-term consequence. Indeed, Orenstein (2000) finds that although countries with more "veto actors" adopted less-radical pension reform, compromises made in the coalition-building process dramatically enhance $d$ the subsequent level of support for and compliance with the pension reform in the implementation phase.

Elsewhere, when faced with political institutions that spread power broadly, governments have employed a variety of ad hoc mechanisms that can overcome these potential stumbling blocks. Such mechanisms range from technocratic governments with decree powers in Italy to informal cross-party agreements in Germany and formal multiparty working groups in Sweden (Schludi, 2002, chapter 9). Clearly the availability of a multi-party working group-which in turn reflected a longer history of cross - party political cooperation-was very important in facilitating the Swedish NDC reform. On the other hand, inability to work across parties has clearly paralyzed Social Security reforms in the United States in the post-1983 period.

Ultimately, the design of political institutions, whether concentrating power or spreading it broadly across parties and actors in government obliges reformers to make important trade -offs in the pension reform process. Indeed, while evidence to support a systematic relationship between the concentration of political power and the depth of 
reform achieved remains mixed, it is clear that in the end, strategic political actors play a powerful role in bringing the issue of pension reform to the policy agenda, and mediating the competing tensions of building a broad coalition to assure the permanency of the reform, while preserving the main policy initiatives sought in the reform process.

\section{Policy Design}

The discussion to this point has emphasized features of the political and social context in whichNDC-based pension reforms may reach the policyagenda and win adoption. But the chances of success in adopting reform may also depend on the exact provisions of an NDC reform package - notably who is covered by it, how quickly it is phased in, which groups are afforded special protections, and how much protection is provided by other pension tiers. For example, seniors' organizations and unions dominated by older workers are more likely to oppose a shift to NDC the faster it is phased in, because that will have a greater impact on their current membership. It is no accident that pension reform initiatives of all kinds generally "grandfather" current retirees and provide generous transition rules protecting older workers from most cutbacks.

NDC schemes offer reforming governments, especially those in fragmented, multi-party political systems-a way to resolve the diverse objectives of coalition partners from opposing ends of the ideological spectrum, and thus may facilitate the creation of legislative majorities behind this significant structural reform. For governments pressed by demographic and economic changes to reduce long-term state pension liabilities (in an unfunded DB pension system), the tighter link between contributions and benefits in the DC mechanism presents a key means to achieve this objective. Yet, unlike funded-DC schemes, the creation of a large NDC com ponent to 
mandatory pension systems will not alienate parties that are either skeptical about the privately-managed pension schemes, or view a central role for the state in the pension system as the sine qua non of social security. By retaining the pay-as-you-go financing structure, and moreover by permitting legislative control over the notional interest rate, NDC reforms may conciliate the demands of parties seeking to protect bureaucratic jobs and the central role for the state in the collection and allocation of benefits. Moreover, the aspects of NDC reforms that permit the government either to deliver privileges to constituencies such as the uniformed services, or to reward socially-valued activities such as child-rearing, higher education or military service, provide a variety of bargaining tools with which the government can propitiate interest groups or parties that oppose the NDC reform. If reformers are able to tailor NDC-inspired reforms to fit local policy, political and social conditions, they may be able to move their countries from nonadoption to at least partial adoption of NDC reforms.

\section{Evaluating Determinants and Explaining Patterns of Reform}

The diffusion of NDC-based pension reform is clearly a complex, multi-causal process. Even the long list of potential influences on adoption or rejection of NDC reform outlined in Table 3 does not exhaust the list of plausible causal variables

influencing the spread of NDC-based reforms. ${ }^{21}$ Moreover, the patterns shown in Table 4 do not reveal simple one-to-one relationships between specific independent variables and particular outcomes: causal effects are more aptly characterized as probabilistic and interactive rather than as individually necessary or sufficient.

Sweden's role as NDC innovator illustrates these patterns. Sweden's serious aging problem as well as a financial crisis and resistance to higher payroll taxes helped put pension reform on the Swedish agenda in the early 1990s, as similar 
economic/demographic constraints did in many other countries. High technocratic capacity and a fairly even balance (and change in control of government) between Social Democratic and non-socialist forces, as well as the more idiosyncratic factors of a strong technocratic orientation in the working group planning the pension reform and the exclusion of "social partners" from a direct role in negotiations (Lundberg, 2003, Lindbom, 2001; Anderson and Weaver, forthcoming) all help to explain why Sweden was the first framework legislation for NDC-based reform. But Sweden's relatively open political system, and in particular, grassroots opposition within Sweden's powerful bluecollar labor confederation and the Social Democratic party explain why it took another four years for final legislation to be adopted.

Clearly both regional networks and supra-national institutions were important in explaining the diffusion of NDC-based reforms beyond its origins in Sweden to other relatively early innovators like Latvia and Poland. Both Swedish experts and the World Bank played particularly important roles in spreading these ideas. But as Orenstein (2003: 174) suggests, theories that focus on the diffusion of ideas through regional networks are not very helpful in understanding when, where and how NDC-based reforms will be altered to fit local conditions by lengthening transition periods, excluding specific groups from the reform, or deciding on the relative size of an NDC-based tier within a multi-pillar pension system. To answer these questions, approaches that focus on polic y feedbacks, societal interests and political conditions are needed.

Policy feedbacks play a particularly important role in advanced industrial countries. Among these countries, NDC based reforms have spread primarily among countries where "Bismarckian" s ocial insurance principles of earnings replacement in the public pension system are deeply ingrained rather than those where a flat-rate system (New Zealand) or a mixed public-private system (the United Kingdom, Switzerland) is in 
place. Younger and less generous "Bismarckian Lite" countries (the United States and Canada) are also less likely to see NDC-based reforms on the agenda, at least in the near future.

Policy feedback effects are less clear in the developing and transitional economies of Central and Eastern Europe, however, where NDC-based reforms have been enacted even in the absence of adequate wage records and a strongly earnings-related precursor system. In these countries, regional and supra-national influences appear to be more important. And in Africa and East Asia where public pension coverage rates are generally much lower, NDC-based reforms have barely made a ripple. These patterns of regionally uneven policy feedback effects are likely to change over time: as NDC-based reforms become fully diffused over the next decade or so among pension policy experts world-wide, regional network biases and supra-national institution effects in adoption of NDC-based reform may weaken in the developing and transitional economies.

\section{IMPLEMENTATION CHALLENGES}

Adopting notional defined contribution-based pension reforms can be an important mechanism for restraining pension costs and generating a closer link between individuals' contributions and benefits, as has been discussed above. But adoption of reform is only half of the battle. As Eric Patashnik (2003) has shown, major policy reforms are subject to erosion or reversal once they are enacted. Developing constituencies who have a stake in the new policy is particularly important to sustaining policy innovation.

In the case of NDC-based pension reforms, erosion is probably a greater risk than outright reversal. Indeed, erosion of NDC-based reforms may be attractive to governments because it offers short-term political gains (or avoids short-term political 
costs) while the effects of those actions on the sustainability of the system may not be immediately obvious. As Table 5 suggests, this erosion could occur in any of the key attributes that define an NDC-based pension system. For example, gover nments might choose to impute contributions or rights that have not actually been financed, either for all contributors (as in Italy) or for certain groups (e.g., caregivers, university students). In countries where the government has chosen to finance all non-contributory benefits (e.g., for caregivers) from the general budget, there may be a temptation to simply impute those credits during periods of fiscal stress. Statistical agencies could also be pressured not to make projections that trigger politically unpopular benefit changes - e.g., projections of increased longevity or long-term economic growth. While this may not be a problem in countries where statistical agencies are well-established, highly professionalized, and enjoy a high degree of independence, status and deference, it could certainly be a problem in some developing and transitional countries where none of these things are true. Governments may also be tempted to use NDC contributions to pay some of the costs for pension tiers outside the NDC system that maintain benefit adequacy for selected segments of the elderly population as NDC is phased in rather than using them to build a buffer fund.

Because NDC systems are not completely different from existing DB pensions, but there are in fact "partial" NDC positions (as shown in the fourth column in Table 1), the big challenge of policymakers in NDC systems is likely to be to hold the line against reforms that move from NDC provisions to middle positions (e.g., retaining brakes, but with a cap; temporary increases in contribution rates; infusions of general revenue to keep real benefits from falling; imputing contributions that are purely notional rather than real; moving from universal coverage of NDC to exclusion of privileged categories of workers). The 1995 Latvian pension reform, for example, went into effect immediately, 
reducing benefits for a significant portion of workers retiring in 1996, while generating vast disparities in pension benefits. ${ }^{22}$ The Latvian transition rules, however, were poorly designed and in some cases unfair for persons without work a work in the informal sector (Palmer, Stabina, Svensson and Vanonvska, 2005 forthcoming). This created a popular backlash, and placed intense pressure on politicians to revisit the pension reform law in October 1997 and March 1998, when a series of measures were adopted that provided a more generous transition rule for computing initial capital based on oldsystem records and contribution records during the turbulent 1990s. In practice, this enhanced the generosity of benefits and reinstated some degree of redistribution to the system to compensate for the economic turbulence of the 1990s. In addition, politicians in Latvia voted an extra indexation of benefits for all pensioners in1997 and 1998, reflecting an effective pensioners lobby (Palmer, Stabina, Svensson and Vanonvska, 2005 forthcoming). In Poland, changes made in 1999 moved new hires in the uniformed services out of the NDC pension system back into a more generous DB system enjoyed by current employees in the uniformed services

Several factors may lead to the erosion of NDC-based pension reforms. Most generally, the political party or coalition that instituted the reform may lose power to another political grouping that is hostile to the reform - that may indeed have used opposition to the reform as a key plank in their electoral campaign. Table 5 suggests several conditions that may also lead to the erosion of specific components of an NDCbased reform. As noted above, a government fiscal crisis is particularly likely to erode a government's commitment to make actual contributions in recognition of nonemployment activities (e.g., child-care years and unemployment spells). A short-term cash flow crunch as a result of a demographic "bulge" may tempt governments to raise payroll taxes rather than inject general revenues even though doing so increases the long- 
term liabilities of the system. Unrest among the military or a strike threat from public transit workers may lead to their return to a more generous DB system. A decline in the overall labor force and wage bill may leave a government unwilling to cut annuity benefits for retirees and account balances for current workers. In short, like decisions on adopting a public pension system, both economic/demographic factors and societal factors are likely to affect final outcomes.

Having an NDC-based system in place does shift the bargaining leverage in favor of those who want to put greater financial discipline in the pension system, because preventing the system's erosion requires them merely to block changes proposed by politicians or groups catering to short-term constituency interests rather than adopting new policies. This advantage is likely to be important in political systems (a) where the governing party or coalition has sufficient agenda control to keep reform-eroding proposals off the agenda; and (b) with multiple veto points, where super-majorities are usually needed to move from the default position. But where agenda control is weak and where veto points are fewer and weaker, temptations for politicians to loosen the lashes will remain strong.

The most essential element to sustaining a complete NDC model once it has been adopted is likely to be the maintenance of a broad multi-party agreement in government that NDC is the right thing to do, and broad public understanding of, and support for the reform. So far, this agreement within the government appears to be holding in Sweden, the home of the NDC idea. However, public opinion surveys suggest that even after several years of multi-media public information campaigns, most citizens lack basic knowledge of the fundamental precepts (and even the name) of the NDC scheme. As Sundén(Sundén, 2005 forthcoming) argues, because DC sys tems make it difficult for individuals to anticipate their retirement benefits, it is important for citizens to have a 
strong understanding of how benefits are determined under the new system, and how this has changed from the former DB scheme, if they are to make informed decisions on how much to work and save. From a political standpoint, moreover, improving public information about NDC reforms, and their implications for long-term benefits may be a crucial factor in avoiding the backlash experienced in Latvia in 1996 when pension benefits diverged radically from public expectations.

Whether Swedish experience of broad political consensus sustaining an NDCbased pension system can be repeated in countries where traditions of inter-party cooperation are weaker, trade unions are less cooperative, and politicians have stronger incentives to respond to independently organized groups of seniors, remains to be seen. Although the public information campaign carried out by the Social Insurance Board in Sweden likew ise represents a model for many countries, evidence that a majority of Swedes lack basic knowledge of the NDC component of the pension system, and that a majority also perceive that they have significant information needs, should serve as an important warning to politicians as to the risk of public backlash in the future if citizens over-estimate their old age income protection and fail to save adequately (Sundén, 2003). Moreover, if such information problems exist in small, affluent and highly educated nations such as Sweden, successful public information campaigns will likely be even more difficult in the developing and transitional countries.

\section{PROSPECTS AND POTENTIAL PROBLEMS}

Notional defined contribution pension reforms are likely to be an important part of pension reformers' "toolkits" in the years ahead. For technocrats, NDC packages combine conceptual elegance and the promise of fiscal discipline that is seen to be lacking in most DB pension plans. For politicians, NDC plans combine an aura of 
fairness (in relating contributions to benefits) that can be explained to voters with the prospect that those politicians will in the future be spared from dealing with politically painful benefit cutbacks and payroll tax increases. The "a utomaticity" of NDC is likely to give it continuing appeal to blame-avoiding politicians, especially in countries with social insurance based systems and moderate debt/GDP ratios. This automaticity also makes NDC appealing to international financial institutions seeking to promote sustainable fiscal policies.

Indeed, a political analysis of NDC-based reforms suggests that there is a central contradiction in the political appeal of NDC-based reforms: technocrats are attracted to NDC because in its "complete" form it sends clear signals to workers on the need to work longer and the need to save for retirement in order to obtain an adequate pension. The problem, however, is that transparency on these issues may kill prospects for NDC-based reform, since workers are likely to object to making these changes, especially older workers who have limited time to adjust and blue-collar workers for whom working longer may be more difficult or even impossible. Politicians, on the other hand, are likely to be attracted to NDC for precisely the opposite reason: it can hide the magnitude of future recipient losses vis-à-vis the policy status quo because 1) from the perspective of the 'average' citizen, NDC benefit determinations are more opaque than DB plansalthough the latter may also be less exposed to future political risk; and (2) future cutbacks are contingent on future economic and demographic developments. There are strong incentives for politicians not to be clear about the likely effects of an NDC-based reform on individual workers if they hope to succeed in adopting and sustaining that reform. But this in turn may undercut many of the hoped-for effects of NDC-based reforms on retirement and savings behavior, and the political sustainability of the NDC reform itself. 
Overall, the analysis in this paper suggests that NDC is no panacea. Six issues in particular are important in considering the prospects for NDC-based reforms. First, there are limitations to the applicability of NDC systems. For countries w ith the weakest states, lacking the administrative capacity to collect and maintain adequate contribution records on a consistent basis, NDC systems are not likely to be workable. At a minimum, the phase-in period in such countries will have to be very long to develop such a capacity. Moreover, in countries where public pensions have not historically had a close linkage to earnings (e.g., countries with a flat-rate pension), a shift to an NDC is likely to impose substantial losses for some recipients. Again, a long lead time is likely to be necessary to lessen political opposition to such a shift. In countries where NDC reforms are applied retrospectively, conflicts over transition rules for crediting past contributions are likely to be intense, and subject to multiple revisions to respond to the grievances of particular constituencies.

Second, there is a danger that adoptions of incomplete and flawed NDC pension plans, as in Italy, may lull politicians into a false sense of complacency that they have "solved" their long-term pension problems when they have not. As both politicians and constituencies become more familiar with the dynamics of NDC pensions, the probability grows rather than shrinks that compromises will be built into reform packages that undercut their effectiveness and sustainability. Like a photocopy of a photocopy of a photocopy that still bears the original image in a perceptible but fuzzy way, future NDC pension regimes in some countries may be called NDC, and have many of their elements, but lack fiscal and political sustainability.

Third, adoption of NDC-based pension reforms are no panacea for providing political cover for long-term pension retrenchment. It still requires that politicians refrain from the politically easy course of demanding more generous pension benefits for visible 
groups of constituents, and that they refrain from going along when other politicians make those demands. It also requires that politicians refrain from political interference with "buffer funds" where they exist. There is no such thing as a "manipulation-proof reform" pension or otherwise but there are more political risk-resistant political institutions and policy structures.

Fourth, while the novelty of NDC schemes and the contingency of future benefits on economic and demographic factors affords politicians a unique opportunity to rationalize state pensions without confronting strong opposition ex ante, these factors also enhance the need for effective political management of information and guidance of public expectations as to the value of future pension benefits. The Swedish strategy of providing workers with annual statements showing the evolution of notional account balances is emblematic of good public information and expectations management. Campaigns such as these diminish the risk that the government will face a political backlash if benefits under the NDC scheme diverge widely from public expectations.

A fifth potential shortcoming of NDC-based pension reform flows directly from the periodic information about balances in individual notional accounts that in theory should be provided to participants in an NDC system. As Daniele Franco pointed out in comments on an earlier draft of this paper: when NDC is enacted in a flawed or incomplete manner that is likely to require further changes in the future, this information can in fact make those further reforms politically much more difficult. Notional account balance statements give workers a much greater sense of "property rights" in the balances in those accounts by making them much more visible. If a future reform, for example, were to eliminate pension rights for contributions that were credited but not actually made, the balances in the accounts would shrink. A major public uproar would likely result over politicians “stealing” their money—a politician's worst nightmare. Similarly, 
if expected increases in longevity are not included in statements regularly, it could lead to sudden drops in the benefit flow expected from account balances when they are included. Such changes will lead both to a decline in confidence in the pension system and to political problems for politicians.

Finally, while the stabilization of contribution rates remains an important concern, it should be emphasized that NDC pension systems transfer significant new risks to individuals, notably the risk of lower benefits due to poor macroeconomic performance and the risk of being able to find appropriate (or any) work at an advanced age if workers are expected to stay in employment longer to main tain a replacement rate similar to that enjoyed by current retirees (Scherman, 2003). The risk of poverty in old age remains a significant policy risk, especially in many developing and transitional nations, and may increase under NDC-based systems over the equivalent risk in what for many countries is the most likely alternative: continued ad hoc adjustments in underfinanced DB schemes. In particular, the reluctance of politicians to make unpopular adjustments to the parameters of pension systems may raise the longer-term risk that the cost of increasing longevity will be borne primarily in the value of pension benefits, which may erode pensions below a socially-accepted level. ${ }^{23}$ Thus the political advantages of NDC reforms in allowing politicians to avoid blame for costly benefit reductions may also give rise to a longer-term social cost if old age pensions fail to provide sufficient protection against the risk of poverty in aging societies. This risk may be especially high in political systems with multiple veto points where the policy default position is privileged.

Thus it is important for governments to balance the goals of stabilizing or reducing payroll taxes with other political and social objectives in designing overall pension reforms. In the Latvia n case, for instance, the authors of the Latvia Human Development Report 2000/2001 observe that "[t]he average Latvian pension still remains 
considerably below the value of the minimum goods and services basket, although the difference between these two indicators is steadily diminishing" (Bite and Zagorskis, 2003:63). Despite the increase in pension values, cost-saving measures passed in 1999 were expected to significantly decrease pension values in 2000 and 2001, more than half of which were already at the minimum value, due to early problems in the design of the transitional rules (Bite and Zagorskis, 2003:64). In Latin America as well, given that a large portion of pensions granted are at the minimum level, efforts to control costs through benefit reduction alone should take into consideration issues of adequacy and poverty reduction when considering how to accommodate demographic change. In these cases, raising the retirement age and promoting higher individual savings offer alternative mechanisms to enhance the financial stability of public pension schemes without drastically lowering benefits.

Increasing the linkage between pension contributions and benefits will also almost certainly require supplementation of NDC benefits with "social pensions" if they are to provide adequate minimum benefits. This is true in both rich and poor countries, but it is especially true in LDC and transitional economies. Social pensions complementing an NDC-based tier can be structured in several ways: as a universal pension received by all, or as a pension that is tested against income, income and assets, or (as in Sweden), only against other pension income. It can also be financed in a variety of ways, notably through a separate payroll tax or general revenues.

Our overall conclusion is thus unsurprising but critical: NDC-based reforms are likely to work best in countries that have the political capacity to achieve and sustain a broad political agreement and the administrative capacity to produce independent forecasts of economic and demographic trends and complete and accurate records of earnings, as well as ensuring compliance and adequate understanding on the part of 
employers and employees. They are less likely to work well where those capacities are lacking. NDC should not, therefore, be thought of as a simple way to avoid the political dilemmas of pension politics by securely lashing politicians to the mast of an automatically adjusting pension system. Neither the mast nor the lashings are that strong, and the sirens' call remains very powerful in many countries. Moreover, a shift from DB to NDC-based pensions, while they do lower financial risks over an FDC system and may lower political risks over those in a financially unsustainable DB scheme, are nevertheless likely to increase workers' fears and uncertainty about their future pension incomes and create new employability risks for older workers

Thus while NDC-based reforms can be an important part of the pension reform repertoire for both domestically based politicians and expert groups and for trans-national actors (including international financial institutions), there is no substitute for a careful analysis of a country's political and social environment and administrative capacity to determine how such a reform is likely to work on the ground. NDC at best is likely to be the least undesirable of many imperfect alternatives in achieving pension reforms that balance fiscal sustainability, adequacy and fairness within and across generations. 
Table 1. Non-Financial Pension Provisions as a Continuum from Defined Benefit to Defined Contribution

\begin{tabular}{|c|c|c|c|c|}
\hline Provision & Defined Benefit & $\begin{array}{l}\text { Middle Position DB } \\
\text { Reforms }\end{array}$ & $\begin{array}{l}\text { "Weak" or "Partial" } \\
\text { NDC }\end{array}$ & $\begin{array}{l}\text { "Strong" or "Full" } \\
\text { NDC }\end{array}$ \\
\hline \multicolumn{5}{|l|}{$\begin{array}{l}\text { Structural } \\
\text { Features }\end{array}$} \\
\hline Funding & $\begin{array}{l}\text { Entirely Pay-As- } \\
\text { You-Go }\end{array}$ & $\begin{array}{l}\text { May have some } \\
\text { advanced funding, } \\
\text { usually for liquidity } \\
\text { purposes }\end{array}$ & $\begin{array}{l}\text { Entirely Pay-As-You- } \\
\text { Go }\end{array}$ & $\begin{array}{l}\text { Reserves built up for } \\
\text { large demographic } \\
\text { cohorts, to hold } \\
\text { transfers from general } \\
\text { budget and for long- } \\
\text { term system balance }\end{array}$ \\
\hline $\begin{array}{l}\text { Years of } \\
\text { earnings and } \\
\text { contributions } \\
\text { incorporated } \\
\text { in benefit ru le }\end{array}$ & $\begin{array}{l}\text { Can include } \\
\text { anything from no } \\
\text { work (but residency } \\
\text { or nationality) } \\
\text { requirement to } \\
\text { specified years of } \\
\text { contributions } \\
\text { (including "best } \\
\text { years" and "final } \\
\text { salary" } \\
\text { arrangements) }\end{array}$ & $\begin{array}{l}\text { Replacement rate } \\
\text { based on number of } \\
\text { years that corresponds } \\
\text { to the entire working } \\
\text { life for typical worker }\end{array}$ & $\begin{array}{l}\text { May include some } \\
\text { non-financed credits } \\
\text { for non-work activities }\end{array}$ & $\begin{array}{l}\text { Full link between } \\
\text { contributions and } \\
\text { earnings }\end{array}$ \\
\hline $\begin{array}{l}\text { Life } \\
\text { Expectancy at } \\
\text { retirement }\end{array}$ & $\begin{array}{l}\text { No provision in } \\
\text { benefit calculation }\end{array}$ & $\begin{array}{l}\text { Inclusion of } \\
\text { "demographic factor" } \\
\text { in benefit calculation } \\
\text { to fully or partially } \\
\text { compensate for } \\
\text { population aging }\end{array}$ & $\begin{array}{l}\text { Infrequent or } \\
\text { incomplete (e.g., } \\
\text { exclusion of post - } \\
\text { retirement) adjustment } \\
\text { for increases in } \\
\text { longevity; no } \\
\text { automatic mechanism } \\
\text { to correct for } \\
\text { incomplete changes } \\
\end{array}$ & $\begin{array}{l}\text { Benefit levels adjust } \\
\text { fully (including } \\
\text { current retirees) and } \\
\text { automatically for } \\
\text { increases in longevity }\end{array}$ \\
\hline $\begin{array}{l}\text { Retirement } \\
\text { age }\end{array}$ & $\begin{array}{l}\text { Fixed standard } \\
\text { retirement age (may } \\
\text { include actuarial } \\
\text { adjustments for } \\
\text { earlier or later } \\
\text { retirement; may be } \\
\text { ad hoc increases in } \\
\text { retirement age over } \\
\text { time) }\end{array}$ & $\begin{array}{l}\text { Flexible retirement } \\
\text { age and/or automatic } \\
\text { increases in retirement } \\
\text { age to fully or partially } \\
\text { compensate for } \\
\text { longevity increases }\end{array}$ & $\begin{array}{l}\text { Minimum age to claim } \\
\text { benefit, but no } \\
\text { standard retirement } \\
\text { age. Inadequate } \\
\text { adjustment for earlier } \\
\text { or later retirement }\end{array}$ & $\begin{array}{l}\text { Minimum age to claim } \\
\text { benefit, but no } \\
\text { standard retirement } \\
\text { age. Partial retirement } \\
\text { possible. Full actuarial } \\
\text { adjustment for earlier } \\
\text { or later and partial } \\
\text { retirement }\end{array}$ \\
\hline $\begin{array}{l}\text { Inflation and } \\
\text { economic } \\
\text { growth }\end{array}$ & $\begin{array}{l}\text { Benefits adjusted for } \\
\text { inflation and/or } \\
\text { earnings increases, } \\
\text { sometimes with ad } \\
\text { hoc changes to } \\
\text { restrain costs }\end{array}$ & $\begin{array}{l}\text { Benefits adjusted for } \\
\text { inflation and/or } \\
\text { earnings increases; } \\
\text { indexation rule } \\
\text { incorporates brakes for } \\
\text { poor economic } \\
\text { performance and high } \\
\text { inflation, which may } \\
\text { or may not be } \\
\text { followed in practice }\end{array}$ & $\begin{array}{l}\text { Benefits adjusted with } \\
\text { inflation and/or } \\
\text { earnings. Incomplete } \\
\text { brakes for poor } \\
\text { economic performance } \\
\text { and/or government } \\
\text { makes ad hoc } \\
\text { adjustments in brake } \\
\text { to enhance electoral } \\
\text { prospects }\end{array}$ & $\begin{array}{l}\text { Benefits adjusted with } \\
\text { the internal rate of } \\
\text { return, which is tied } \\
\text { fully to earnings } \\
\text { growth }\end{array}$ \\
\hline Financing & $\begin{array}{l}\text { M ay include payroll } \\
\text { taxes and/or general } \\
\text { revenues; revenues } \\
\text { adjusted to needs of } \\
\text { PAYG system on } \\
\text { automatic or ad hoc } \\
\text { basis }\end{array}$ & $\begin{array}{l}\text { Payroll taxes fixed "in } \\
\text { theory" at maximum } \\
\text { target level (e.g., } \\
\text { below } 10 \% \text { in Canada, } \\
20 \% \text { in Germany) but } \\
\text { may be revised in } \\
\text { practice }\end{array}$ & $\begin{array}{l}\text { Payroll tax rate with } \\
\text { part of contribution } \\
\text { rate used to cover } \\
\text { pension rights granted } \\
\text { but not covered by } \\
\text { individual's own } \\
\text { contribution }\end{array}$ & $\begin{array}{l}\text { Fixed payroll tax rate; } \\
\text { all contributions paid } \\
\text { give an NDC account } \\
\text { value, and all non- } \\
\text { contributory rights are } \\
\text { financed externally } \\
\text { (e.g., with general } \\
\text { revenues) }\end{array}$ \\
\hline
\end{tabular}




\begin{tabular}{|c|c|c|c|c|}
\hline $\begin{array}{l}\text { Redistribution } \\
\text { across } \\
\text { generations }\end{array}$ & $\begin{array}{l}\text { First generations } \\
\text { generally winners as } \\
\text { in "Ponzi" scheme }\end{array}$ & $\begin{array}{l}\text { May be restricted } \\
\text { within DB tiers by } \\
\text { lowering replacement } \\
\text { rates and tying } \\
\text { contribution rates to } \\
\text { level needed to be } \\
\text { self-sustaining over } \\
\text { long-term }\end{array}$ & $\begin{array}{l}\text { Credits given to some } \\
\text { cohorts for which no } \\
\text { contributions were } \\
\text { made; possible } \\
\text { generational } \\
\text { redistribution due to } \\
\text { shifting labor market }\end{array}$ & $\begin{array}{l}\text { Possible generational } \\
\text { redistribution due to } \\
\text { shifting labor market }\end{array}$ \\
\hline $\begin{array}{l}\text { Redistribution } \\
\text { within } \\
\text { generations }\end{array}$ & $\begin{array}{l}\text { Permitted within } \\
\text { DB tier, based on } \\
\text { limited number of } \\
\text { "high years" on } \\
\text { which benefits are } \\
\text { based, higher } \\
\text { replacement rates } \\
\text { for low-earners, } \\
\text { credits given for } \\
\text { which no } \\
\text { contributions have } \\
\text { been made }\end{array}$ & $\begin{array}{l}\text { May be restricted } \\
\text { within DB tiers by } \\
\text { increasing number of } \\
\text { years on which } \\
\text { benefits are replaced, } \\
\text { eliminating or } \\
\text { reducing replacement } \\
\text { rate differentials and } \\
\text { limiting credits for } \\
\text { non-wage activity }\end{array}$ & $\begin{array}{l}\text { Some credits given for } \\
\text { activities for which no } \\
\text { contributions were } \\
\text { made }\end{array}$ & $\begin{array}{l}\text { Barred within NDC } \\
\text { tier unless financed by } \\
\text { payments from } \\
\text { government or others } \\
\text { with respect to non- } \\
\text { employment activity. } \\
\text { Exception: NDC } \\
\text { implicitly redistributes } \\
\text { from men to women } \\
\text { and other population } \\
\text { sub-groups with } \\
\text { longer life-expectancy } \\
\text { if single annuitization } \\
\text { table is used }\end{array}$ \\
\hline Coverage & No NDC coverage & & $\begin{array}{l}\text { Only some sectors } \\
\text { (e.g., private sector) } \\
\text { are covered by NDC } \\
\text { system }\end{array}$ & $\begin{array}{l}\text { All workers in } \\
\text { specified age cohorts } \\
\text { are covered by NDC } \\
\text { system }\end{array}$ \\
\hline Time horizon & $\begin{array}{l}\text { No coverage of } \\
\text { NDC system }\end{array}$ & $\begin{array}{l}\text { Later cohorts of } \\
\text { workers covered by } \\
\text { "quasi-NDC" reforms } \\
\text { (e.g., life expectancy } \\
\text { adjustments to benefits } \\
\text { or retirement age) } \\
\end{array}$ & $\begin{array}{l}\text { Only some cohorts } \\
\text { (e.g., new labor } \\
\text { market entrants or } \\
\text { those under age 50) } \\
\text { covered by NDC } \\
\text { system } \\
\end{array}$ & $\begin{array}{l}\text { All employed workers, } \\
\text { including those in } \\
\text { labor force at time } \\
\text { NDC introduced, } \\
\text { covered by NDC } \\
\text { system }\end{array}$ \\
\hline Exclusivity & $\begin{array}{l}\text { No NDC pension } \\
\text { tier }\end{array}$ & N.A. & $\begin{array}{l}\text { NDC-based pension is } \\
\text { only one of several } \\
\text { public pension tiers }\end{array}$ & $\begin{array}{l}\text { NDC is only public } \\
\text { pension tier }\end{array}$ \\
\hline
\end{tabular}


Table 2. The NDC Pension Continuum in Practice

\begin{tabular}{|c|c|c|c|}
\hline Provision & $\begin{array}{l}\text { Sweden (NDC } \\
\text { initiator; full NDC) }\end{array}$ & $\begin{array}{l}\text { Poland } \\
\text { (Full NDC) }\end{array}$ & $\begin{array}{l}\text { Germany } \\
\text { (middle position DB) }\end{array}$ \\
\hline $\begin{array}{l}\text { Advanced } \\
\text { Funding }\end{array}$ & $\begin{array}{l}\text { PAYG plus buffer } \\
\text { fund partially } \\
\text { accumulated under } \\
\text { old pension system }\end{array}$ & $\begin{array}{l}\text { PAYG + Buffer fund } \\
\left(\text { surplus in } 1^{\text {st }} \text { pillar + }\right. \\
\text { privatization revenue } \\
+1 \% \text { temporary } \\
\text { contribution) }\end{array}$ & $\begin{array}{l}\text { PAYG with general } \\
\text { revenues and "eco- } \\
\text { tax" as well as payroll } \\
\text { tax; small } \\
\text { "sustainability } \\
\text { reserve" }\end{array}$ \\
\hline $\begin{array}{l}\text { Life } \\
\text { Expectancy at } \\
\text { retirement }\end{array}$ & $\begin{array}{l}\text { Unis ex, account } \\
\text { balances and } \\
\text { benefits adjusted } \\
\text { both before and after } \\
\text { retirement }\end{array}$ & $\begin{array}{l}\text { Unisex, but calculated } \\
\text { for life expectancy at } \\
\text { the age of retirement }\end{array}$ & $\begin{array}{l}\text { Benefits adjust for } \\
\text { changes in system } \\
\text { dependency ratio }\end{array}$ \\
\hline $\begin{array}{l}\text { Retirement } \\
\text { age }\end{array}$ & $\begin{array}{l}\text { Flexible, with NDC } \\
\text { and FDC pensions } \\
\text { drawable no earlier } \\
\text { than age } 61 \text {; partial } \\
\text { withdrawal possible }\end{array}$ & $\begin{array}{l}\text { minimum: } \\
60 \text { (women) } \\
65 \text { (men) }\end{array}$ & $\begin{array}{l}\text { Normal retirement age } \\
\text { of } 65 \text {; incentives for } \\
\text { early retirement being } \\
\text { reduced }\end{array}$ \\
\hline $\begin{array}{l}\text { Inflation and } \\
\text { economic } \\
\text { growth }\end{array}$ & $\begin{array}{l}\text { Account balances } \\
\text { and benefits } \\
\text { adjusted for wage } \\
\text { growth (initial } \\
\text { benefit is higher } \\
\text { than actuarial } \\
\text { amount and adjusted } \\
\text { for wage growth } \\
\text { minus } 1.6 \text { percent) }\end{array}$ & $\begin{array}{l}\text { accumulation is wage } \\
\text { growth + labor force } \\
\text { growth; annuities } \\
\text { indexed to consumer } \\
\text { prices, unless real } \\
\text { wages are falling, in } \\
\text { which case they are } \\
\text { uprated in line with } \\
\text { nominal wages (i.e., } \\
\text { cut in real terms) }\end{array}$ & $\begin{array}{l}\text { Benefits adjusted for } \\
\text { wage growth }\end{array}$ \\
\hline $\begin{array}{l}\text { Payroll tax } \\
\text { rate }\end{array}$ & $\begin{array}{l}\text { Fixed at } 16 \% \text { for } \\
\text { NDC tier and } 2.5 \% \\
\text { for FDC tier }\end{array}$ & $\begin{array}{l}12.22 \% \text { to } \mathrm{NDC} \\
7.3 \% \text { to } \mathrm{FDC}\end{array}$ & $\begin{array}{l}\text { Government } \\
\text { commitment to hold } \\
\text { contribution rate to no } \\
\text { higher than } 20 \text { percent } \\
\text { through } 2020 \text { and } 22 \\
\text { percent through } 2030\end{array}$ \\
\hline $\begin{array}{l}\text { Redistribution } \\
\text { across } \\
\text { generations } \\
\end{array}$ & $\begin{array}{l}\text { Eliminated once } \\
\text { NDC system is fully } \\
\text { phased in }\end{array}$ & & \\
\hline
\end{tabular}




\begin{tabular}{|l|l|l|l|}
\hline $\begin{array}{l}\text { Redistribution } \\
\text { within } \\
\text { generations }\end{array}$ & $\begin{array}{l}\text { In pension annuity, } \\
\text { from shorter-lived to } \\
\text { longer-lived } \\
\text { pensioners, and } \\
\text { from men to } \\
\text { women. }\end{array}$ & $\begin{array}{l}\text { In pension annuity, } \\
\text { from shorter-lived to } \\
\text { longer-lived } \\
\text { pensioners, and from } \\
\text { men to women. }\end{array}$ & $\begin{array}{l}\text { In pension annuity, } \\
\text { from shorter-lived to } \\
\text { longer-lived } \\
\text { pensioners, and from } \\
\text { men to women. }\end{array}$ \\
\hline \hline Coverage & Universal & $\begin{array}{l}\text { Not universal; } \\
\text { separate programs for } \\
\text { farmers and uniformed } \\
\text { services }\end{array}$ & Universal \\
\hline \hline Time horizon & $\begin{array}{l}\text { Persons born 1938- } \\
\text { 1953 receive } \\
\text { benefits partially in } \\
\text { old system. Persons } \\
\text { born 1954 and later } \\
\text { receive benefits } \\
\text { entirely in new } \\
\text { system. }\end{array}$ & $\begin{array}{l}\text { New system } \\
\text { mandatory for all born } \\
\text { beginning in 1949; } \\
\text { FDC mandatory for } \\
\text { people born after 31, } \\
\text { December, 1968. }\end{array}$ & $\begin{array}{l}\text { Phases in beginning in } \\
\text { 2005 }\end{array}$ \\
& $\begin{array}{l}\text { No. Combined with } \\
\text { smaller FDC tier } \\
\text { and inflation- } \\
\text { indexed guarantee } \\
\text { pension for those } \\
\text { with low lifetime } \\
\text { earnings. }\end{array}$ & $\begin{array}{l}\text { No. Combined with } \\
\text { FDC system, plus tax- } \\
\text { financed minimum } \\
\text { pension supplement } \\
\text { for minimum 25 yrs. } \\
\text { Contributions) if } \\
\text { NDC+FDC annuities } \\
\text { are below minimum. }\end{array}$ & $\begin{array}{l}\text { No.Quasi-mandatory } \\
\text { "zero-pillar" added }\end{array}$ \\
\hline \hline Exclusivity \\
\hline \hline
\end{tabular}

Poland information is from Góra and Rutkowski (2000) and Chlon-Dominczak and Góra (2003). 
Table 3. Potential Relationships between Structural Variable and NDC Choice

\begin{tabular}{|c|c|c|c|c|c|c|c|}
\hline & & Innovation & $\begin{array}{l}\text { Early "full" } \\
\text { adoption }\end{array}$ & $\begin{array}{l}\text { Partial and/or Non- } \\
\text { Exclusive } \\
\text { Adoption } \\
\end{array}$ & Later adoption & $\begin{array}{l}\text { Consideration } \\
\text { but Rejection }\end{array}$ & $\begin{array}{l}\text { Never Reaches } \\
\text { Agenda }\end{array}$ \\
\hline \multirow[t]{3}{*}{$\begin{array}{l}\text { Economic/ } \\
\text { Demographic } \\
\text { Constraints }\end{array}$} & $\begin{array}{l}\text { Aging } \\
\text { pressure }\end{array}$ & $\begin{array}{l}+ \text { Very strong } \\
\text { demographic aging } \\
\text { pressures }\end{array}$ & $\begin{array}{l}\text { Very strong } \\
\text { demographic aging } \\
\text { pressures }\end{array}$ & $\begin{array}{l}+ \text { Strong demographic } \\
\text { aging pressures }\end{array}$ & $\begin{array}{l}\text { - Moderate but } \\
\text { increasing } \\
\text { demographic } \\
\text { aging pressures }\end{array}$ & $\begin{array}{l}\text { - Weak } \\
\text { demographic } \\
\text { aging pressures }\end{array}$ & $\begin{array}{l}\text { - Weak } \\
\text { demographic } \\
\text { aging pressures }\end{array}$ \\
\hline & $\begin{array}{l}\text { Fiscal } \\
\text { pressure }\end{array}$ & \begin{tabular}{|l|}
+ Very high budget \\
deficits and \\
debt/GDP ratio
\end{tabular} & $\begin{array}{l}+ \text { High budget deficits } \\
\text { and debt/GDP ratio }\end{array}$ & $\begin{array}{l}+ \text { Funded DC likely to } \\
\text { play relatively } \\
\text { larger role than } \\
\text { NDC in multi-tier } \\
\text { system where } \\
\text { budget deficits and } \\
\text { debt/GDP ratio are } \\
\text { low } \\
\end{array}$ & $\begin{array}{l}+ \text { Moderate but } \\
\text { increasing budget } \\
\text { deficits and } \\
\text { debt/GDP ratio }\end{array}$ & $\begin{array}{l}\text { Declining } \\
\text { budget } \\
\text { pressure and } \\
\text { debt/GDP ratio }\end{array}$ & $\begin{array}{l}\text { + Low budget } \\
\text { deficits and } \\
\text { debt/GDP ratio }\end{array}$ \\
\hline & $\begin{array}{l}\text { Payroll tax } \\
\text { rates }\end{array}$ & $\begin{array}{l}+ \text { + Very high payroll } \\
\text { tax rates }\end{array}$ & $\begin{array}{l}+ \text { Very high payroll } \\
\text { tax rates }\end{array}$ & + High payroll tax rates & $\begin{array}{c}+ \text { High or rising } \\
\text { payroll tax rates }\end{array}$ & & $\begin{array}{l}\text { - Low payroll tax } \\
\text { rates or no } \\
\text { payroll tax } \\
\end{array}$ \\
\hline \multirow[t]{2}{*}{$\begin{array}{l}\text { Ideational } \\
\text { Forces }\end{array}$} & $\begin{array}{l}\text { Strength of } \\
\text { domestic } \\
\text { forces } \\
\text { favoring } \\
\text { market-based } \\
\text { pension } \\
\text { reform }\end{array}$ & $\begin{array}{l}+ \text { Strong exposure to } \\
\text { international } \\
\text { economic ideas }\end{array}$ & $\begin{array}{l}\text { - Funded DC rather } \\
\text { than NDC more } \\
\text { likely to be adopted } \\
\text { where ideologically } \\
\text { conservative forces } \\
\text { are very strong. }\end{array}$ & $\begin{array}{l}\text { Funded DC likely to } \\
\text { play relatively larger } \\
\text { role than NDC in } \\
\text { multi-tier system } \\
\text { where ideologically } \\
\text { conservative forces } \\
\text { are fairly strong }\end{array}$ & & & $\begin{array}{l}\text { + Funded DC } \\
\text { rather than NDC } \\
\text { more likely to be } \\
\text { adopted where } \\
\text { ideologically } \\
\text { conservative } \\
\text { forces are very } \\
\text { strong. } \\
\end{array}$ \\
\hline & $\begin{array}{l}\text { Participation } \\
\text { in regional } \\
\text { networks } \\
\text { where NDC } \\
\text { ideas } \\
\text { common }\end{array}$ & Not applicable & $\begin{array}{l}\text { Participation in } \\
\text { regional networks } \\
\text { with earlier } \\
\text { adopters; view } \\
\text { earlier adopters as } \\
\text { peer countries }\end{array}$ & $\begin{array}{l}\text { Participation in } \\
\text { regional networks } \\
\text { with earlier } \\
\text { adopters; view } \\
\text { earlier adopters as } \\
\text { peer countries }\end{array}$ & $\begin{array}{l}\text { Outside regional } \\
\text { networks } \\
\text { including early } \\
\text { adopters } \\
=\text { Regional network } \\
\text { effect should } \\
\text { dissipate as NDC } \\
\text { ideas are fully } \\
\text { diffused inter- } \\
\text { nationally } \\
\end{array}$ & & $\begin{array}{l}\text { + Country is } \\
\text { outside regional } \\
\text { networks of early } \\
\text { NDC adopters } \\
\text { = Regional } \\
\text { network effect } \\
\text { should dissipate } \\
\text { as NDC ideas are } \\
\text { fully diffused } \\
\text { inter- } \\
\end{array}$ \\
\hline
\end{tabular}




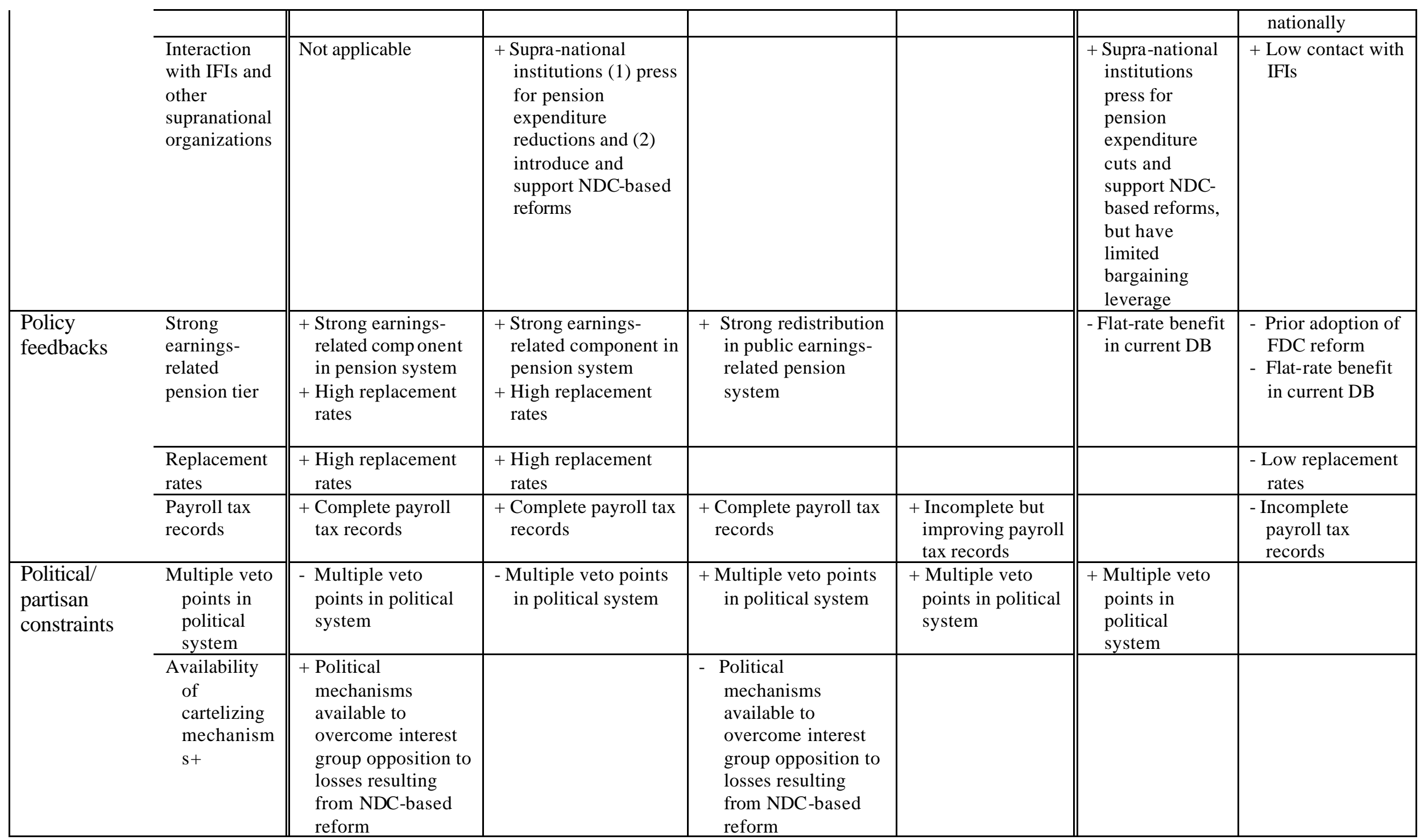

+ Condition makes it more likely that country will be in this category

- Condition makes it less likely that country will be in this category

= Condition makes it likely that effects of other variables of this type will become less important in their effects

Blank cells indicate no hypothesized relationship between this condition and outcome category 
Table 4. Country Characteristics and NDC Reform Outcomes

\begin{tabular}{|c|c|c|c|c|c|c|}
\hline Country & & Sweden & Italy & Germany & Uruguay & United States \\
\hline Outcome & & $\begin{array}{l}\text { Full NDC system } \\
\text { adopted }\end{array}$ & $\begin{array}{l}\text { Partial NDC } \\
\text { system adopted } \\
\text { with long phase- } \\
\text { in }\end{array}$ & $\begin{array}{l}\text { Elements of NDC } \\
\text { adopted, retracted } \\
\text { and readopted }\end{array}$ & $\begin{array}{l}\text { Mixed DB- } \\
\text { Funded DC } \\
\text { reform. }\end{array}$ & $\begin{array}{l}\text { NDC not on } \\
\text { agenda }\end{array}$ \\
\hline \multirow[t]{3}{*}{$\begin{array}{l}\text { Economic/ } \\
\text { Demographic } \\
\text { Constraints }\end{array}$} & $\begin{array}{l}\text { Aging pressure } \\
\text { (\% population } \\
65+\text { in } \\
\text { parentheses })\end{array}$ & $\begin{array}{r}\text { Very high } \\
(17.4 \%)\end{array}$ & $\begin{array}{r}\text { Very high } \\
(17.8 \%)\end{array}$ & $\begin{array}{r}\text { Very high } \\
(16.1 \%)\end{array}$ & "High (12.9\%) & "High (12.3\%) \\
\hline & Fiscal pressure & $\begin{array}{l}\text { Very strong in } \\
\text { early } 1990 \text { s }\end{array}$ & Very strong & Very strong & Very strong & Moderate \\
\hline & $\begin{array}{l}\text { Payroll tax rates } \\
\text { (total payroll } \\
\text { tax rates in } \\
\text { parentheses) }\end{array}$ & High $(26.09 \%$ & $\begin{array}{l}\text { Very high } \\
(41.11 \%)\end{array}$ & $\begin{array}{l}\text { Very high } \\
(40.91 \%)\end{array}$ & $\begin{array}{r}\text { Very high } \\
(35.5 \%)\end{array}$ & $\begin{array}{r}\text { Moderate } \\
(22.7 \%)\end{array}$ \\
\hline \multirow[t]{3}{*}{ Ideational Forces } & $\begin{array}{l}\text { Strength of } \\
\text { domestic forces } \\
\text { favoring } \\
\text { market-based } \\
\text { pension reform }\end{array}$ & Weak & Weak & Fairly weak & Weak & Strong \\
\hline & $\begin{array}{l}\text { Interaction with } \\
\text { IFIs and other } \\
\text { supranational } \\
\text { organizations }\end{array}$ & No & $\begin{array}{l}\text { No interaction } \\
\text { with IFIs, but EU } \\
\text { pressure to reduce } \\
\text { pension spending }\end{array}$ & $\begin{array}{l}\text { No interaction } \\
\text { with IFIs, but EU } \\
\text { pressure to reduce } \\
\text { pension spending }\end{array}$ & $\begin{array}{l}\text { Yes, with Inter- } \\
\text { American } \\
\text { Development } \\
\text { Bank, which } \\
\text { presented NDC } \\
\text { option in } 1992 .\end{array}$ & No \\
\hline & $\begin{array}{l}\text { Participation in } \\
\text { regional networks } \\
\text { where NDC ideas } \\
\text { common }\end{array}$ & $\begin{array}{l}\text { Became hub of } \\
\text { network }\end{array}$ & Yes & Yes & No & No \\
\hline \multirow[t]{3}{*}{ Policy feedbacks } & $\begin{array}{l}\text { Strong earnings- } \\
\text { related pension } \\
\text { tier }\end{array}$ & Yes & Yes & Yes & Yes & Yes \\
\hline & $\begin{array}{l}\text { Replacement } \\
\text { rates }\end{array}$ & Very high & Very high & Very high & High & Moderate \\
\hline & $\begin{array}{l}\text { Complete payroll } \\
\text { tax records }\end{array}$ & Yes & Yes & Yes & No & Yes \\
\hline
\end{tabular}




\begin{tabular}{|ll||l|l|l|l|l|}
\hline $\begin{array}{l}\text { Political/ } \\
\text { partisan } \\
\text { constraints }\end{array}$ & $\begin{array}{l}\text { Multiple veto } \\
\text { points in political } \\
\text { system? }\end{array}$ & Weak & Strong & Weak & Strong & Strong \\
\hline $\begin{array}{l}\text { Mechanisms for } \\
\text { overcoming } \\
\text { policy gridlock? }\end{array}$ & Strong & Mixed & Declining & Weak & Weak \\
\hline
\end{tabular}

Source for data on aging and payroll tax rates: U.S. Social Security Administration, Social Security Programs Throughout the World, most recent editions. 
Table 5. Potential Erosion in NDC Pension Systems

\begin{tabular}{|c|c|c|c|}
\hline Provision & "Strong" or "Full" NDC & Erosion possibilities & Conditions facilitating erosion \\
\hline $\begin{array}{l}\text { Advanced } \\
\text { Funding }\end{array}$ & $\begin{array}{l}\text { PAYG with inclusion of buffer funds in benefit } \\
\text { calculations }\end{array}$ & $\begin{array}{l}\text { Government transfers funds from } \\
\text { buffer funds to general Treasury }\end{array}$ & Government experiences fiscal crisis \\
\hline $\begin{array}{l}\text { Life } \\
\text { Expectancy at } \\
\text { retirement }\end{array}$ & $\begin{array}{l}\text { Future benefit levels adjust automatically for } \\
\text { increases in longevity }\end{array}$ & $\begin{array}{l}\text { Government freezes annuitization } \\
\text { tables }\end{array}$ & $\begin{array}{l}\text { Weak rules in place on regularity and automaticity of } \\
\text { life expectancy adjustments } \\
\text { Weak autonomy of statistical agencies }\end{array}$ \\
\hline Retirement age & $\begin{array}{l}\text { No standard retirement age with full actuarial } \\
\text { adjustment for earlier or later and partial } \\
\text { retirement }\end{array}$ & $\begin{array}{l}\text { Higher non-actuarial benefits re- } \\
\text { established for workers who have } \\
\text { reached a specified age or number } \\
\text { of years in employment }\end{array}$ & Strong unions; pensions become electoral issue \\
\hline $\begin{array}{l}\text { Inflation and } \\
\text { economic } \\
\text { growth }\end{array}$ & Benefits tied fully to economic growth & $\begin{array}{l}\text { Government continues inflation } \\
\text { adjustments in annuities and } \\
\text { account balances when economy is } \\
\text { shrinking }\end{array}$ & Economic recession and/or decline in labor force \\
\hline Payroll tax rate & Fixed payroll tax rate & $\begin{array}{l}\text { Increase in payroll tax } \\
\text { Decrease in payroll tax rate }\end{array}$ & $\begin{array}{l}\text { NDC tier experiences cash-flow crisis resulting from } \\
\text { demographic "bulge" } \\
\text { Government seeks economic stimulus during recession }\end{array}$ \\
\hline $\begin{array}{l}\text { Redistribution } \\
\text { across } \\
\text { generations }\end{array}$ & Barred within NDC tier & $\begin{array}{l}\text { Transition rules made more } \\
\text { generous after initial NDC } \\
\text { implementation }\end{array}$ & $\begin{array}{l}\text { Transition rules in place create highly visible } \\
\text { disparities between adjacent cohorts of retirees }\end{array}$ \\
\hline $\begin{array}{l}\text { Redistribution } \\
\text { within } \\
\text { generations }\end{array}$ & $\begin{array}{l}\text { Barred within NDC tier unless financed by } \\
\text { payments from government or others with respect } \\
\text { to non-employment activity. Exception: NDC } \\
\text { implicitly redistributes from men to women and } \\
\text { other population sub-groups with longer life- } \\
\text { expectancy if single annuitization table is used }\end{array}$ & $\begin{array}{l}\text { Government imputes NDC credits } \\
\text { for non-employment activity rather } \\
\text { than actually making contributions }\end{array}$ & Government experiences fiscal crisis \\
\hline Coverage & $\begin{array}{l}\text { All workers in specified age cohorts are covered } \\
\text { by NDC system }\end{array}$ & $\begin{array}{l}\text { Favored groups win exclusion from } \\
\text { NDC reform after initial inclusion }\end{array}$ & $\begin{array}{l}\text { Favored groups have strong leverage in political } \\
\text { system (e.g., public sector unions, military) }\end{array}$ \\
\hline Time horizon & $\begin{array}{l}\text { All employed workers, including those in labor } \\
\text { force at time NDC introduced, covered by NDC } \\
\text { system }\end{array}$ & $\begin{array}{l}\text { Time horizon for phase-in of NDC } \\
\text { pension extended }\end{array}$ & $\begin{array}{l}\text { Transition rules in place create highly visible } \\
\text { disparities between adjacent cohorts of retirees }\end{array}$ \\
\hline Exclusivity & NDC is only public pension tier & $\begin{array}{l}\text { New means-tested tier or minimum } \\
\text { guarantee created or existing one } \\
\text { expanded after implementation of } \\
\text { NDC }\end{array}$ & $\begin{array}{l}\text { Income inequality or poverty among the elderly } \\
\text { increase after implementation of NDC system (May } \\
\text { also be pressures for expanding pension guarantee } \\
\text { outside NDC tier if that benefit is not automatically } \\
\text { adjusted for wage growth) }\end{array}$ \\
\hline
\end{tabular}




\section{BIBLIOGRAPHY}

Anderson, Karen M. and R. Kent Weaver (forthcoming) "Pension Policymaking in Sweden: Fundamental Reforms in a Policy Cartel,' in Weaver Reforming Public Pensions: Lessons from Abroad.

Bite, Inara, and Valdis Zagorskis (2003) "Study on the Social Protection Systems in the 13 Applicant Countries: Latvia Country Study," Gesellschaft für

Versicherungswissenscchaft und -gestaltung e.V.

Bennett, Colin J. (1991) "What is Policy Convergence and What Causes It?" British Journal of Political Science vol. 21, pp. 215-233.

Blöndal, Sveinbjörn, and Stefano Scarpetta (1997) "Early Retirement in OECD Countries: The Role of Social Security Systems, OECD Economic Studies, 29, pp. 7-53.

Bonoli, Giuliano (2000) The Politics of Pension Reform, Cambridge: Cambridge University Press.

Börsch, Supan, Axel and Christine B. Wilke (2003) "The German Pension System: How It Was, How It Will Be" In Robert Holzman and Edward Palmer, eds. Non-Financial Defined Contribution Pensions. Washington D.C.: World Bank.

Brooks, Sarah (1998) "Political Dynamics of Pension Reform in Argentina" Paper presented at the International Meeting of the Latin American Studies Association, Chicago, Illinois.

Brooks, Sarah (2001) Social Protection and the Market. Ph.D. dissertation, Department of Political Science, Duke University

Brooks, Sarah (2002) "Social Protection and Economic Integration: The Politics of Pension Reform in an Era of Capital Mobility," Comparative Political Studies, vol. 35, no. 5 (June) pp. 491-523.

Brooks, Sarah (forthcoming) "Interdependent and domestic sources of policy change: the diffusion of pension privatization around the world" International Studies Quarterly.

Brooks, Sarah (2004a) "International Financial Institutions and the Diffusion of Foreign Models for Social Security Reform in Latin America?," pp. 53-80 in Kurt Weyland, ed. Learning from Foreign Models in Latin American Policy Reform. Washington, DC: Woodrow Wilson Center Press, and Johns Hopkins University Press.

Brooks, Sarah (2004b) “A Competing Risks Model of Structural Pension Reform,” Paper presented at the annual meeting of the American Political Science Association, Chicago, Illinois, September 2-5, 2004. 
Chlon-Dominczak, Agnieszka, and Marek Góra (2005 forthcoming) “The NDC System in Poland, Assessment After Five Years," In Robert Holzman and Edward Palmer, eds. Non-Financial Defined Contribution Pensions. Washington D.C.: World Bank.

Cohen, Michael D., James G. March, Johan P. Olsen (1972) “A Garbage Can Model of Organizational Choice," Administrative Science Quarterly, Vol. 17, No. 1. (March), pp. 1-25.

D’Alimonte, Roberto (2001) "Mixed Electoral Rules, Partisan Realignment, and Party System Change in Italy," pp. 323-350 in Matthew Soberg Shugart and Martin P Wattenberg, eds. MixedMember Electoral Systems: the Best of Both Worlds?, New York: Oxford University Press.

Dawson, Murrell E., and Elfreda Chatman (2001) "A reference group theory with implications for information studies: a theoretical essay." Information Research vol. 6, no. 3.

Diamond, Peter (2000) Social Security Reform, Oxford: Oxford University Press.

Elster, Jon (1979) Ulysses and the Sirens, Cambridge: Cambridge University Press.

Elster, Jon (2000) Ulysses Unbound : Studies in Rationality, Precommitment, and Constraints, Cambridge: Cambridge University Press.

European Union, Economic Policy Committee (2001) Budgetary Challenges Posed by Ageing Populations, Brussels, EPC/ECFIN/655-EN-fin, October 24.

Finnemore, Martha (1993) "International Organizations as Teachers of Norms." International Organization 47, 4 (Fall) pp. 565-599.

Fox, Louise and Edward Palmer 1999) "Latvian Pension Reform" Social Protection Discussion Paper \#9922 (August, 1999) Washington, DC: The World Bank.

Franco, Daniele and Nicola Sartor (2005 forthcoming) "Notional Defined contribution in Italy: Unsatisfactory Present, Uncertain Future" In Robert Holzman and Edward Palmer, eds. NonFinancial Defined Contribution Pensions. Washington D.C.: World Bank.

Garrett, Geoffrey (1998) Partisan Politics in the Global Economy. Cambridge, UK: Cambridge University Press.

Gern, Klaus -Jürgen (2002) "Recent Developments in Old Age Pension Systems: An International Overview," pp. 439-478 in Martin Feldstein and Horst Siebert, eds., Social Security Pension Reform in Europe, Chicago: University of Chicago Press.

Gill, Indermit S., Truman Packard and Juan Yermo (2004) Keeping The Promise Of Old Age Income Security In Latin America: A Regional Study Of Social Security Reform, Washington, D.C.: World Bank. 
Góra, Marek and Michael Rutkowski, “The Quest for Pension Reform: Poland's Security through Diversity" Working Paper Number 286 (January, 2000) Washington, DC: The World Bank.

Haas, Peter M. (Winter, 1992) "Introduction: Epistemic Communities and International Policy Coordination,” International Organization 46, 1: 1-35.

Hering, Martin (2004) Rough Transition: Institutional Change in Germany's 'Frozen' Welfare State, Baltimore: Johns Hopkins University Ph.D. Dissertation.

Holzmann, Robert (2005 forthcoming) "Toward a Reformed and Coordinated Pension System in Europe: Rationale and Potential Struc ture" In Robert Holzman and Edward Palmer, eds. Non-Financial Defined Contribution Pensions. Washington D.C.: World Bank.

Hunter, Wendy and David S. Brown (2000) World Bank Directives, Domestic Interests, and the Politics of Human Capital Investment in Latin America. Comparative Political Studies 33(1): 113-143.

Iglesias, Augusto and Robert J. Palacios. (2000) "Managing Public Pension Reserves: Evidence from the International Experience," pp. 213-253 in Holzmann and Stiglitz, eds., New Ideas About Old Age Security.

Immergut, Ellen (1992) "The rules of the game: The logic of health policy-making in France, Switzerland and Sweden." In Kathleen Thelen and Sven Steinmo, Eds. Structuring Politics: Historical Institutionalism in Comparative Perspective. New York: Cambridge University Press.

Kahneman, D., P. Slovic and A. Tversky, eds. (1982) Judgment under uncertainty: Heuristics and biases. New York: Cambridge University Press.

Kay, Stephen (1998). Politics and Social Security Reform in the Southern Cone and Brazil. Ph.D. dissertation, Department of Political Science, University of California, Los Angeles.

Keohane, Robert O. and Joseph Nye (1974) "Transgovernmental Relations and International Organizations.” World Politics 27, 1 (October) pp.39-62

Kingdon, John (1995) Agendas, Alternatives, and Public Policies [second edition], New York: HarperCollins.

Kinsella, Kevin, and Victor A. Velkoff (2001) An Aging World: 2001, Washington, D.C.: U.S. Government Printing Office, 2001, U.S. Census Bureau, Series P95/01-1.

Krasner, Stephen (1985) Structural Conflict: The Third World Against Global Liberalism. Berkeley, CA: University of California Press. 
Light, Paul (1995) Still Artful Work: The Continuing Politics of Social Security Reform, New York: McGraw-Hill.

Lindbom, Anders (2001) "De borgerliga partierna och pensionsreformen", pp. 50-87 in Joakim Palme (ed.), Hur blev den stora kompromissn mojlig. Politiken bakom den svenska pensionsreformen, Stockholm: Pensionsforum.

Lundberg, Urban (2003) Juvelen I kronan: Social demokraterna och den allmänna pensionen, Stockholm: Hjalmarson and Högberg, 2003.

Madrid, Raúl (2003) Retiring the State: The Politics of Pension Privatization in Latin America and Beyond, Stanford: Stanford University Press.

Moravsik, Andrew (1993) "Integrating International and Domestic Theories of International Bargaining," pp. 3-42, in Robert Putnam, ed., Double-Edged Diplomacy: International Bargaining and Domestic Politics, Berkeley: University of California Press.

Most, Benjamin A. and Harvey Starr. (December, 1980) Diffusion, Reinforcement, Geopolitics, and the Spread of War. The American Political Science Review 74, 4: 932946.

Murillo, Victoria (2001) Labor Unions, Partisan Coalitions, and Market Reforms in Latin America, Cambridge University Press.

Nelson, Joan M. (2004) "External Models, International Influence, and the Politics of Social Sector Reforms," pp. 35-52 in Kurt Weyland, ed. Learning from Foreign Models in Latin American Policy Reform. Washington, DC: Woodrow Wilson Center Press, and Johns Hopkins University Press.

Orenstein, Mitchell A. (2003) "Mapping the Diffusion of Pension Innovation," pp. 171-193 in Robert Holzmann, Mitchell Orenstein and Michal Rutkowski, eds. Pension Reform in Europe: Process and Progress. Washington, D.C: The World Bank.

Orenstein, Mitchell (March, 2000) 'How Politics and Institutions Affect Pension Reform in Three Postcommunist Countries.” Policy Research Working Paper Series, No. 2310, Washington, D.C.: The World Bank.

Pal, Leslie, and R. Kent Weaver (2003). The Government Taketh Away: The Politics of Pain in the United States and Canada, Washington, D.C. Georgetown University Press.

Palacios, Robert J. (2002) Managing Public Pension Reserves Part II: Lessons from Five Recent OECD Initiatives, World Bank Social Protection Discussion Paper No. 0219.

Palmer, Edward (2005 forthcoming) "Conversion to NDC: Issues and Models." In Robert Holzman and Edward Palmer, eds. Non-Financial Defined Contribution Pensions. Washington D.C.: World Bank. 
Palmer, Edward (2005 forthcoming). "Conversion to NDC: Issues and Models.” In Robert Holzman and Edward Palmer, eds. Non-Financial Defined Contribution Pensions. Washington D.C.: World Bank.

Palmer, Edward and Marek Góra (2005 forthcoming). "Shifting Perspectives in Pensions" In Robert Holzman and Edward Palmer, eds. Non-Financial Defined Contribution Pensions. Washington D.C.: World Bank.

Palmer, Edward, Sandra Stabina, Ingemar Svensson and Inta Vanovska (2005 forthcoming). "NDC in Latvia" In Robert Holzman and Edward Palmer, eds. Non-Financial Defined Contribution Pensions. Washington D.C.: World Bank.

Palmer, Edward (2005 forthcoming). "What Are NDCs_-A Primer". In Robert Holzman and Edward Palmer, eds. Non-Financial Defined Contribution Pensions. Washington D.C.: World Bank.

Patashnik, Eric (2003) "After the Public Interest Prevails: The Political Sustainability of Policy Reform," Governance, vol. 16, no. 2 (April) pp. 203-234.

Pierson, Paul D. Dismantling the Welfare State, Cambridge: Cambridge University Press, 1994.

Pierson, Paul (1998) "Irresistible Forces, Immovable Objects: Post-Industrial Welfare States Confronting Permanent Austerity," Journal of European Public Policy, Volume 5, No. 4, (December) pp. 539-60.

Pierson, Paul (2000) "Increasing Returns, Path Dependence, and the Study of Politics," American Political Science Review, vol. 94, no. 2, pp. 251-67.

Pierson, Paul, ed. (2001) The New Politics of the Welfare State, Oxford: Oxford University Press.

Pierson, Paul, and R. Kent Weaver (1993) "Imposing Loses in Pension Policy" in R. Kent Weaver and Bert A. Rockman (Eds.). Do Institutions Matter? Washington D.C.: The Brookings Institution, pp. 110-150.

Pinheiro, Vinícius and Solange Viera (2000) "Reforma previsional en Brasil: La nueva regla para el cálculo de los beneficios" Serie Financiamiento del Desarrolo No. 97 Santiago de Chile: CEPAL.

Pinheiro, Vinícius (2004) “The Politics of Social Security Reform in Brazil,” pp. 110-138 in Kurt Weyland, ed. Learning from Foreign Models in Latin American Policy Reform. Washington, DC: Woodrow Wilson Center Press, and Johns Hopkins University Press.

Putnam, Robert D. (1998) "Diplomacy and Domestic Politics: The Logic of Two-Level Games," International Organization, vol. 42, no. 3 (Summer) pp. 427-460 
Scherman, K.G. (2003) “Old Age Security in Sweden, Quo Vadis?,” Ppaer delivered at the Forschungsnetzwerkes Alterssichung, Erfurt, December 45.

Schludi, Martin (2002) The Reform of Bismarckian Pension Systems, Berlin: Humbold University Ph.D. Dissertation.

Slater, David W., and William B.P. Robson (1999) Building A Stronger Pillar: The Changing Shape of the Canada Pension Plan, Toronto: C.D. Howe Research Institute.

Sundén, Annika (2005 forthcoming) "How much do people need to know about their pensions and what do they know?" In Robert Holzman and Edward Palmer, eds. Non-Financial Defined Contribution Pensions. Washington D.C.: World Bank.

Swank, Duane (1998) "Funding the Welfare State: Globalization and the Taxation of Business in Advanced Market Economies," Political Studies 46, no. 4, pp. 671-92.

Swank, Duane and Sven Steinmo (2002) "The New Political Economy of Taxation in Advanced Capitalist Democracies." American Journal of Political Science vol. 46, no. 3, pp. 477-89.

Tavits, Margit (2003) "Policy Learning and Uncertainty: The Case of Pension Reform in Estonia and Latvia," Policy studies Journal, vol. 31, no. 4.

Tsebelis, George (1999) "Veto players and law production in parliamentary democracies: An empirical analysis," American Political Science Review vol. 93, pp. 591-608.

Tversky, Amos and Daniel Kahneman(1974) "Jugement Under Uncertainty: Heuristics and Biases." Science, vol.185, pp. 1124-1131.

Weaver, R. Kent (1986) "The Politics of Blame Avoidance," Journal of Public Policy, 6,4, pp. 371-398.

Weaver, R. Kent (1988) Automatic Government: The Politics of Indexation, Washington, D.C.: The Brookings Institution.

Weaver, R. Kent (2004) "Whose Money Is It Anyway? Governance and Social Investment in Collective Investment Funds," pp. 294-316 in Martin Rein and Winfried Schmähl eds., Rethinking the Welfare State: The Political Economy of Pension Reform, Cheltenham: Edward Elgar.

Weyland, Kurt (2004) "Conclusion: Lessons About Learning in Latin American Policy Reform," pp. 241-283 in Kurt Weyland, ed. Learning from Foreign Models in Latin American Policy Reform. Washington, DC: Woodrow Wilson Center Press, and Johns Hopkins University Press.

World Bank (2001) Notional Accounts: Notional Defined Contribution Plans as a Pension Reform Strategy," Pension Primer Notes. 


\section{ENDNOTES}

${ }^{1}$ The research reported herein was partially funded pursuant to a grant from the U.S. Social Security Administration (SSA) funded as part of the Retirement Research Consortium at Boston College. The opinions and conclusions are solely those of the authors and should not be construed as representing the opinions or policy of SSA or any agency of the Federal Government. The authors would like to thank Daniele Franco, Agneta Kruse and Edward Palmer for extensive and helpful comments on an earlier draft of this chapter. The order of authorship is alphabetical, rather than representative of relative contributions to this project.

${ }^{2}$ While Palmer and Góra (2003) emphasize the financial stability of NDC pension schemes, Kruse 2003 argues that there remains a possibility of financial instability in NDC systems unless there is an automatic balancing mechanism (as in Sweden.) Agneta Kruse, (2002): "Ageing populations and intergenerational risk-sharing in payg pension schemes." WP 2002:18, Dept of Economics, Lund University. www.nek.lu.se/publications.

${ }^{3}$ In this respect, the Swedish NDC scheme follows the practice of the pre-reform Swedish earnings-related pension. But buffer funds are by no means unique to Sweden, or to NDC systems. A number of other countries faced with deteriorating demographic situations have developed such funds in their defined-benefit pension programs, including the United States, Canada, and (more recently) New Zealand. See Palacios and Iglesias, 2001; Palacios, 2003; Weaver, 2004.

${ }^{4}$ Blöndal and Scarpetta (1997, pp. 17-18), in a survey of 18 OECD countries, found that pension contribution rates rose from an average of 9.3 percent in 1967 to 16.5 percent in 1995; the average contribution rate was 1.88 times its 1967 level in 1995.

${ }^{5}$ A finding of a future deficit in the CPP's triennial review process sets in motion a process under which Ministers from Ottawa and the provinces are supposed to agree on any needed changes to keep the plan viable; if they do not agree, contribution rates will increase automatically to meet half of the anticipated deficiency (phased in over three years), and indexation of the CPP will be frozen for the next three years unless cabinet ministers agree to override these procedures. See Slater and Robson, 1999, pp. 6-7.

${ }^{6}$ The United States invests its reserve fund only in federal securities, however, while the Canada Pension Plan and Quebec Pension Plan invest in a broader range of financial instruments. See Weaver, 2004.

${ }^{7}$ Indeed, the absence of adequate contribution records in Brazil was a crucial obstacle to the creation of an NDC pension reform in that country, see Pinheiro and Viera, 2000.

${ }^{8}$ The Polish government is easing out certain early retirement privileges by financing "bridge pensions" for uniformed services, wherein the government makes additional contributions to finance a pension paid from early retirement age to the normal retirement age established under the 1997 reform law, see Góra and Rutkowski, 2000.

${ }^{9}$ A substantial literature on policy diffusion in a variety of sectors among the American states suggests that innovating states - those who first design and implement a reform-are found predominantly among relatively wealthy states with high technocratic capacity and slack resources (see the discussion in Orenstein, 2003). The fact that NDC was pioneered in Sweden, a wealthy country with strong technocratic capacity in the pension sector, is consistent with this line of argument.

${ }^{10}$ Tavits (2003) in a review of Estonian pension reforms, categorizes causal variables affecting diffusion of innovation into three categories: internal determinants, external pressures and 
lesson-drawing. In Tavits's categories, economic/demographic, policy feedbacks, partisan/political constraints and societal constraints would all fit within the category of internal determinants, while ideational forces would be divided into Tavits's internal (strength of conservative forces), external and lesson-drawing (supra-national institutions) and lesson drawing (regional networks) categories.

${ }^{11}$ Prominent research suggests that individuals are, in essence, "cognitive misers" who, due to their finite information processing abilities, look to cues, heuristics or information shortcuts to make decisions more tractable (see Tversky and Kahneman, 1974, Kahneman, Slovic and Tversky, 1982). Brooks (2003) has argued that competitiveness and status concerns were significant influences in the adoption of private pension reforms in developing countries seeking to attract foreign investment, while Hering (2004) has examined the role of such pressures in European nations seeking accession to the European Union.

12 Brooks (1998) found that in Argentina, in order to gain leverage over domestic opponents to an FDC pension reform proposal, President Menem requested that the IMF place a condition in its Letter of Intent of its March, 1992 Extended Fund Facility Agreement requiring the Argentine government to pass a structural pension reform by January, 1993. For the role of international financial institutions as strategic "scapegoats," see also Vreeland, 1999.

${ }^{13}$ For the attraction argument, see Brooks (forthcoming). Among the transition countries, Bulgaria, Hungary and Latvia received considerable technical and financial support from the World Bank through conditional loans, but only Latvia adopted the NDC model. Nevertheless, the attraction to DC structures among Eastern European and Central Asian countries is striking, with FDC reforms adopted in Estonia, Lithuania, Kazakhstan and (in addition to NDC) in Poland, while NDC was adopted with later addition of an FDC tier in Latvia. Whether these governments chose financial or notional DC schemes may be understood to have been shaped by a combination of financing constraints, explained above, and political dynamics, discussed below.

${ }^{14}$ In Uruguay as well, the IDB played a more important role in transferring ideas and technology of pension reform than in promoting any specific policy model. The research that led up to the (eventually rejected) 1992 NDC reform proposal in Uruguay was financed by a loan from the Inter-American Development Bank, and was based on technical advice from a team of Latin American pension experts, including a Brazilian scholar who later participated in the design of the 1999 pension reform in Brazil that contains some elements similar to NDC.

${ }^{15}$ Although sufficient, the existence of complete payroll tax records is unlikely to be a necessary condition.

${ }^{16}$ Early evidence suggests that the adoption and diffusion of NDC and FDC pension reform models differ systematically in this respect, with governments being more likely to adopt NDC reforms where political institutions share power broadly across parties represented in government, and thus allow reformers to avoid direct blame for costs that become apparent after adoption (Brooks, 2004b).

17 This problem is one that concerns more than simply pragmatic considerations of the likely backlash that elected politicians might incur, but reaches to a core dilemma of public ethics that suggests that in order to do the "right thing," politicians at times must do what citizens would otherwise oppose, such as automatic reductions in pension benefits when pension system revenue declines. For the meta-ethical discussion of the politics of "dirty hands," see Walzer 1973; Parrish, 2002. 
${ }^{18}$ Other aspects of political institutions may also affect capacity for policy change. For example, countries that have relatively short electoral cycles may find it particularly difficult to make changes that impose visible losses on retirees and those approaching retirement. See the discussion in Pal and Weaver (2003) and Bonoli (2000).

${ }^{19}$ See for example Immergut (1992); Kay (1998) and Brooks (2002). The advantages of concentrated power and minimal veto points may, however, be at least partially offset by concentration of accountability in political systems: because voters know that it is the governing party that is imposing losses, governing parties may be reluctant to undertake initiatives that are very likely to incur retribution at the next election (Pierson and Weaver, 1993). Because future losses may be obscured ex ante in NDC reforms, accountability concerns may be partly allayed. Moreover, even governing parties with very strong formal powers may refrain from enacting policies that are likely to be reversed by a later government.

${ }^{20}$ Italy adoped a Mixed-Member Majoritarian (MMM) electoral system in 1993. The new electoral system "did not reduce party fragmentation, but it did provide powerful incentives for parties to enter into pre-electoral coalitions." (D'Alimonte, 2001, p. 323).

${ }^{21}$ For example, in an analysis of the determinants of differences between pension reform in Estonia and Latvia, Targits (2003) argues that a record of successful domestically-initiated economic reform outside the pension sector in Estonia gave Estonian political elites greater confidence that they could successfully design and implement a home-grown pension reform, while a weaker Latvian record in this regard make them more inclined to borrow heavily from the Swedish NDC model. An extension of this argument would be that in countries where previous policy borrowing from supra-national organizations or through regional networks in other sectors has been judged by political elites to be successful, they may be inclined to do it again in the pension sector.

${ }^{22}$ Bite and Zagorskis (2003: 41) report that pensions calculated in January 1997 ranged from as low as 8 Lats, to over 1,000 Lats; which was "shocking to the society" that was accustomed to the traditional equalizing role of social security. In fact, no one actually received such a low pension due to the system's guarantee rule. The high pensions were not the result of NDC rules but to a generous conversion of special privileges acquired under the old system, such as for Latvians forced into exile in Siberia for a large part of their lives. See Palmer, Stabina, Svensson and Vanonvska in Robert Holzman and Edward Palmer, eds. Non-Financial Defined Contribution Pensions. Washington D.C.: World Bank.

${ }^{23}$ Diamond argues that while this diminishes the risk of excessive legislative intervention, the solvency promoted by automatic benefit reductions may enhance the risk that governments intervene too infrequently to balance the demographic adjustment to the contribution formula as well; see Diamond, 2002:86. 


\section{RECENT WORKING PAPERS FROM THE \\ CENTER FOR RETIREMENT RESEARCH AT Boston COLLEGE}

Lashed to the Mast?: The Politics of Notional Defined Contribution Pension Reforms

Sarah Brooks and R. Kent Weaver, January 2005

Changes in the Distribution of Long-Run Earnings and Retirement IncomesHave Recent Cohorts Fallen Behind?

Peter Gottschalk and Minh Huynh, January 2005

The Age Profile of Income and the Burden of Unfunded Transfers in Four Countries: Evidence from the Luxembourg Income Study

Gary Burtless, December 2004

Projecting Immigration: A Survey of the Current State of Practice and Theory Neil Howe and Richard Jackson, December 2004

Nonearnings Income Migration in the United States: Anticipating the Geographical

Impacts of Baby Boom Retirement

Peter B. Nelson, December 2004

Does Work Pay at Older Ages?

Barbara A. Butrica, Richard W. Johnson, Karen E. Smith, and Eugene Steuerle, November 2004

Poverty and Income Maintenance in Old Age: A Cross-National View of Low Income Older Women

Timothy M. Smeeding and Susanna Sandstrom, November 2004

How Does Marriage Affect the Allocation of Assets in Women's Defined Contribution Plans?

Angela C. Lyons and Tansel Yilmazer, November 2004

Why Don't Americans Save?

Barry Bosworth, November 2004

How Do Pensions Affect Expected and Actual Retirement Ages?

Alicia H. Munnell, Robert K. Triest, and Natalia A. Jivan, November 2004

All working papers are available on the Center for Retirement Research website (http://www.bc.edu/crr) and can be requested by e- mail (crr@bc.edu) or phone (617-5521762). 